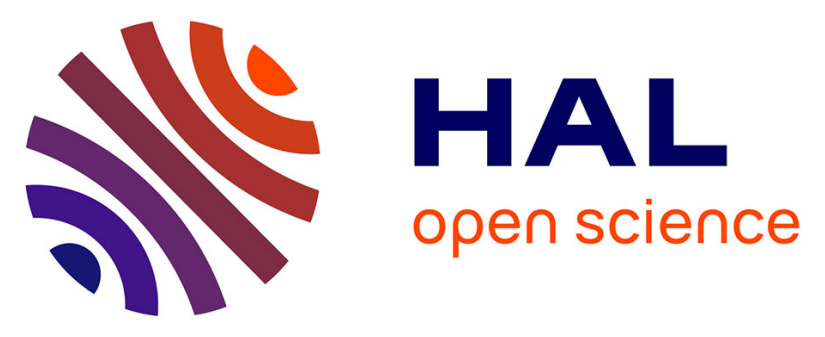

\title{
Monazite U-Th-Pb EPMA and zircon U-Pb SIMS chronological constraints on the tectonic, metamorphic, and thermal events in the inner part of the Variscan orogen, example from the Sioule series, French Massif Central
}

Damien Do Couto, Michel Faure, Romain Augier, Alain Cocherie, Philippe Rossi, Xian-Hua Li, Wei Lin

\section{- To cite this version:}

Damien Do Couto, Michel Faure, Romain Augier, Alain Cocherie, Philippe Rossi, et al.. Monazite $\mathrm{U}-\mathrm{Th}-\mathrm{Pb}$ EPMA and zircon U-Pb SIMS chronological constraints on the tectonic, metamorphic, and thermal events in the inner part of the Variscan orogen, example from the Sioule series, French Massif Central. International Journal of Earth Sciences, 2016, 105, pp.557-579. 10.1007/s00531-015-1184-0 . insu-01167544

\section{HAL Id: insu-01167544 \\ https://hal-insu.archives-ouvertes.fr/insu-01167544}

Submitted on 25 Jun 2015

HAL is a multi-disciplinary open access archive for the deposit and dissemination of scientific research documents, whether they are published or not. The documents may come from teaching and research institutions in France or abroad, or from public or private research centers.
L'archive ouverte pluridisciplinaire HAL, est destinée au dépôt et à la diffusion de documents scientifiques de niveau recherche, publiés ou non, émanant des établissements d'enseignement et de recherche français ou étrangers, des laboratoires publics ou privés.

\section{(2)(1) $\$$}

Distributed under a Creative Commons Attribution - NonCommercial - NoDerivatives $\mid 4.0$ 
1 Monazite U-Th-Pb EPMA and zircon U-Pb SIMS chronological constraints on

2 the tectonic, metamorphic and thermal events in the inner part of the Variscan

3 orogen, example from the Sioule series, French Massif Central

4

5 Damien Do Couto ${ }^{1,2}$, Michel Faure ${ }^{1 *}$, Romain Augier ${ }^{1}$, Alain Cocherie $^{3}$, Philippe Rossi $^{3}$

$6 \quad$ Xian-Hua $\mathrm{Li}^{4}$, Wei $\mathrm{Lin}^{4}$

7

1: Université d'Orléans-CNRS/INSU, Institut des Sciences de la Terre d'Orléans (ISTO),

9 Campus Géosciences, 1A Rue de la Férollerie 45071 Orléans Cedex 2, France

10 (*corresponding author: michel.faure@univ-orleans.fr)

11 2: Département des Sciences de la terre, 13 rue des Maraîchers, 1205 Genève, Switzerland

12 3: BRGM, Av. Claude-Guillemin, BP 36009, 45060 Orléans Cedex 2 France

13 4: State Key Laboratory of Lithospheric Evolution, Institute of Geology and Geophysics,

14 Chinese Academy of Sciences, Beijing 100029, China

\section{Abstract}

16 In the northern Variscan French Massif Central, the Sioule metamorphic series exposes from

17 top to bottom the tectonic superposition of the Upper Gneiss Unit (UGU), Lower Gneiss Unit

18 (LGU), and Para-autochthonous Unit (PAU). The nappe stacking developed throughout two

19 prograde syn-metamorphic events: $\mathrm{D}_{1}$ is a top-to-the $\mathrm{SW}$ shearing coeval with a probable

20 Devonian migmatization, and $\mathrm{D}_{2}$ is a top-to-the NW shearing event. Both events were

21 completed before the unconformable deposition of the undeformed and unmetamorphozed

22 "Tufs anthracifères" formation, dated at ca $330 \mathrm{Ma}$ (Late Visean). Furthermore, the UGU

23 experienced a high pressure metamorphism ascribed to a $\mathrm{D}_{0}$ event during which eclogite or

24 granulite crystallized in several parts of the UGU. Monazite U-Th- $\mathrm{Pb}$, and zircon U-Pb SIMS 
25 datings were carried out in order to constrain the ages of these $\mathrm{D}_{0}, \mathrm{D}_{1}$, and $\mathrm{D}_{2}$ tectonic26 metamorphic events. These new geochronological results are placed in a P-T-t diagram constructed for the UGU, LGU, and PAU. Monazite sampled in UGU, LGU, PAU rocks yields similar 365-350 Ma ages consistent with the $\mathrm{D}_{2}$ event dated in other places of the

29 French Massif Central. A zoned monazite grain from a granulitic paragneiss yields $416 \pm 15$ 30 Ma and $362 \pm 14$ Ma ages interpreted as those of the $\mathrm{D}_{0}$ and $\mathrm{D}_{2}$ events, respectively. Zircon

31 from the same granulitic paragneiss yields SIMS ages at $343 \pm 2 \mathrm{Ma}$, and $328 \pm 2 \mathrm{Ma}$ that are 32 interpreted as recrystallization processes associated with post-thickening thermal events, 33 possibly recording the onset of orogenic collapse of the Northern Massif Central. It is worth 34 to note that neither monazite nor zircon recorded the $\mathrm{D}_{1}$ event.

36 Key words Variscan orogeny, monazite chemistry, monazite U-Th-Pb chemical dating, zircon SIMS geochronology, granulite facies, monazite chemistry, French Massif Central 
41

42

\section{Introduction}

Dating the syn-metamorphic rocks and their related ductile fabrics remains a challenge. Indeed, many of the common metamorphic phases such as biotite, muscovite, feldspar, and amphibole can be dated by the ${ }^{40} \mathrm{Ar} /{ }^{39} \mathrm{Ar}$ method, however it is well acknowledged that this chronometer is highly sensitive to any late thermal perturbation, thus the radiometric ages obtained by this method may represent cooling ages or "re-opening" ages rather than genuine crystallization age of the dated minerals (see Jourdan et al 2014 for a recent review). Zircon is also a common accessory phase used for U-Pb geochronology. Due to analytical improvements, punctual measurements using SIMS, SHRIMP or LA-ICP-MS technique, zircon yields precise age, however as for the ${ }^{40} \mathrm{Ar} /{ }^{39} \mathrm{Ar}$ method, the significance of zircon U$\mathrm{Pb}$ geochronology must be carefully considered for dating metamorphic rocks since zircon may crystallize or recrystallize at various stages of the rock history, including initial magmatism formation stage for igneous protoliths. Monazite that may crystallize either from magma or during metamorphic reactions appears as one of the most useful phase to assess the timing of tectono-metamorphic events. Although separated monazite grains can be dated by SIMS or LA-ICP-MS, the in-situ approach that preserves the textural relationships between minerals allows the deciphering of superimposed magmatic and/or metamorphic hightemperature stages. Furthermore, the size of the analytical spot ( $c$ a $20 \mu \mathrm{m})$ for LA-ICP MS measurements generally prevents this detailed investigation as metamorphic monazite is often small-sized, chemically zoned or partly dissolved. Nevertheless, though involving a nonisotopic technique, with a $c a 5$ to 15 Ma uncertainty, larger than the isotopic methods, the monazite U-Th-Pb EPMA method can provide one of the best estimate of the metamorphic mineral crystallization ages in polymetamorphic terranes. 
in polymetamorphosed and polydeformed domains, particularly when thermo-barometric conditions preclude the use of temperature-sensitive geochronological methods such as ${ }^{40} \mathrm{Ar} /{ }^{39} \mathrm{Ar}$. This paper aims to apply the monazite U-Th-Pb EPMA chemical, and zircon U-Pb SIMS dating methods to the Sioule metamorphic series, in the Northern part of the Variscan French Massif Central since in this area, the tectonic-metamorphic succession is already well established, but radiometric constraints still rare, as presented in the following sections (e.g. Faure et al. 1993, 2002; Schulz et al. 2001; Schulz 2009).

\section{Geological outline of the Variscan French Massif Central}

The stack of nappes

The French Massif Central (FMC thereafter) is an important segment of the Variscan Belt that results of a complex interplay between two main continents, namely Gondwana, and Laurussia, and several intervening microcontinents such as Avalonia, Mid-German

Crystalline Rise, and Armorica (e.g. Matte 2001; Cocks 2000; Faure et al. 2005; Murphy et al. 2011). It is now well acknowledged that the bulk architecture of the French Massif Central, alike the southern part of the Massif Armoricain or the Vosges-Black Forest massif, is a stack of metamorphic nappes developed diachronously from Late Silurian to Early Carboniferous at the expense of the north Gondwana margin (Matte 1986; Ledru et al. 1989; Faure et al. 2005, 2009; Lardeaux et al. 2014; Fig . 1).

From bottom to top, and South to North, the following units are recognized (Figs. 1, 2). 1) The foreland basin develops in the southernmost part of the Massif Central. It is an Early Carboniferous (Visean-Serpukhovian) turbiditic basin that extends southward below the coastal plain of the Mediterranean Sea. 2) The Paleozoic Fold-and-Thrust Belt consists of Early Cambrian to Visean unmetamorphosed sedimentary rocks displaced to the South as 
thrust sheets or kilometre-scale recumbent folds well. There, the Early Devonian (i. e. Lochkovian, 416-411 Ma) unconformity argues for an Early Paleozoic tectonic event (at ca 420-400 Ma), which is also recorded to the North of the Massif Central in the Lower and Upper Gneiss metamorphic units (cf. below). 3) The Para-autochthonous Unit that overthrusts the Paleozoic Fold-and-Thrust Belt is formed by greenschist to epidoteamphibolite facies metapelites, metagreywackes, quartzites, and a small amount of marbles and metabasites. In the northern Massif Central, the Para-autochthonous Unit crops out in tectonic windows surrounded by the Lower Gneiss Unit. In the Cévennes area, some granitic plutons, now transformed into orthogneiss, intruding the series, yield Cambrian to Early Ordovician zircons (Bé Mézème et al. 2006). 4) The Lower Gneiss Unit (LGU) is composed of metagreywackes, metapelites, and metarhyolites intruded by Cambrian to Early Ordovician porphyritic alkaline granitoids transformed into augen orthogneiss during the tectonicmetamorphic events. The LGU underwent a Middle Devonian metamorphism leading to crustal melting coeval with a ductile shearing dated in the Limousin at 375-370 Ma (Faure et al. 2008) and attributed to the $D_{1}$ event (cf below). Moreover, the LGU also experienced a medium pressure/medium temperature metamorphism characterized by a biotite-garnetstaurolite assemblage, dated at ca. 360-350 Ma (Costa 1989; Melleton et al. 2009), and attributed to the $\mathrm{D}_{2}$ event. 5) The Upper Gneiss Unit (UGU) forms the overlying nappe whose the main protoliths are metapelites and metagrauwackes. This unit contains high-pressure rocks, such as eclogites or high pressure (HP) granulitic orthogneiss that may locally reach the coesite-eclogite facies (Santallier 1981; Pin and Vielzeuf 1988; Lardeaux et al. 2001; Berger et al., 2010). The upper part of the UGU consists of Devonian migmatites, yielding zircon U$\mathrm{Pb}$ ages at $\mathrm{ca} 385-380 \mathrm{Ma}$, attributed to the $\mathrm{D}_{1}$ event, and formed by the partial melting of pelitic and quartzo-feldspathic rocks (Duthou et al. 1994; Faure et al. 2008). These rocks contain amphibolite blocks derived from retrogressed eclogites that did not experience partial 
116 melting. The HP metamorphism is dated at ca $420-400 \mathrm{Ma}$ by $\mathrm{U}-\mathrm{Pb}$ and $\mathrm{Sm}-\mathrm{Nd}$ methods in

117 several locations (Pin and Peucat 1986; Paquette et al. 1995; Faure et al. 2005).

118 The five units described above represent the classical nappe pile of the FMC in which the

119 metamorphism increases from bottom to top. Furthermore, in the northern part of the French

120 Massif Central, the undeformed and unmetamorphozed "Tuffs anthracifères" series, which

121 consists of terrigenous rocks (sandstone, shales, conglomerates), coal measures, and felsic

122 magmatic rocks (dacites and rhyolites), is dated as Late Visean (ca $330 \mathrm{Ma}$, Bruguier et al.

123 1998). These rocks unconformably cover Late Devonian-Early Carboniferous plutonic or

124 metamorphic rocks of the UGU and LGU. The "Tuffs anthracifères" series provides a major

125 time constraint for the evolution of the French Massif Central. As the "Tuffs anthracifères"

126 series is coeval with the development of the Fold-and-Thrust Belt, it supports the north-south

127 diachronism in the deformation at the scale of the entire massif.

129 The polyphase tectono-metamorphic evolution

130 The Variscan geodynamic evolution of the French Massif Central remains disputed. Some

131 authors (e.g. Matte 1986; Ledru et al. 1989) consider that the formation of the FMC results of

132 a continuous north-directed oceanic then continental subduction from early Silurian to early

133 Carboniferous. In contrast, other authors (e.g. Pin 1990; Faure et al. 1997, 2008, 2009) argue

134 for a polycyclic evolution. The Early Silurian to Early Devonian events correspond to the Eo-

135 Variscan cycle due the collision of the Armorica microcontinent with the north Gondwana

136 margin. From Middle Devonian to Early Carboniferous, the Variscan belt develops due to the

137 southward subduction of the Rheic Ocean below Gondwana followed by the collision of

138 Gondwana with Laurussia. In spite of differences between the two geodynamic scenarii, most

139 of authors agree on the main tectonic, metamorphic, and magmatic events. Six tectono-

140 metamorphic events are recognized (Faure et al. 2009). 
The earliest event, $\mathrm{D}_{0}$, corresponds to the high to ultra high-pressure metamorphism

142 recorded in the eclogite facies rocks of the UGU. Most of the HP rocks derive from mafic

143 protoliths, but also HP relics are also found in orthogneiss are locally found. In the Lyonnais

144 area, the UGU eclogites record pressure and temperature conditions of 1.8-2 GPa and 650-

$145750^{\circ} \mathrm{C}$, respectively (Lardeaux et al. 2001). On the basis of the HP metamorphism, the $\mathrm{D}_{0}$

146 event took place around $415 \mathrm{Ma}$ (Pin and Peucat 1986).

147 The Early to Middle Devonian, tectonic-metamorphic event $\mathrm{D}_{1}$, is coeval with the

148 crustal melting of the metapelites and orthogneiss of the UGU and LGU, whereas mafic rocks

149 are preserved as amphibolite restitic blocks in migmatites. The migmatisation is dated as

150 Middle Devonian (385-375 Ma) in the Limousin or Lyonnais areas (Duthou et al. 1994, Faure

151 et al. 2008 and enclosed references). P-T estimates from garnet-plagioclase and garnet-biotite

152 pairs in migmatites, indicate metamorphic conditions of $0.7 \pm 0.05 \mathrm{GPa}$ and $700 \pm 50^{\circ} \mathrm{C}$

153 respectively (Mercier et al. 1991; Roig and Faure 2000). The flat-lying foliation exhibits a

154 NE-SW striking (N30 to N60E) stretching lineation marked by fibrolitic sillimanite or biotite

155 in migmatites, and biotite or amphibole in amphibolites. Shear criteria indicate a top-to-the-

156 SW displacement (Ledru et al.1989; Faure et al. 1997; Roig and Faure 2000). Amphibolite in

157 the northern Massif Central yields biotite and hornblende ${ }^{40} \mathrm{Ar} /{ }^{39} \mathrm{Ar}$ cooling ages ranging from

$158390 \mathrm{Ma}$ to 381Ma (Costa and Maluski 1988; Boutin and Montigny 1993). In northeastern

159 Massif Central, or Morvan area, Middle Devonian unmetamorphosed and undeformed

160 sedimentary rocks unconformably overlying migmatites with eclogite relics suggest that, at

161 least in the northern part of the Massif Central, the HP rocks were already exhumed before the

162 Middle Devonian (Faure et al. 1997).

163 In the LGU, UGU, the dominant fabric is a NW-SE trending stretching lineation

164 developed either on flat-lying or steeply dipping foliations, which is attributed to the $\mathrm{D}_{2}$ event

165 (Faure et al. 2005, 2008). Thermo-barometric constraints are well established in the Limousin 
166 and Rouergue areas (Duguet et al. 2006; Bellot and Roig 2007). In the UGU, the syn- $\mathrm{D}_{2}$

167 minerals, crystallized along the NW-SE lineation, indicate $0.7-1 \mathrm{GPa}$ and $600-700^{\circ} \mathrm{C}$

168 metamorphic conditions. Paragneiss belonging to the LGU yield nearly similar conditions of

$169 \quad 0.8-1 \mathrm{GPa}$ and $550-600^{\circ} \mathrm{C}$. In the $\mathrm{LGU}$, amphibolites that never experienced the high-pressure

170 event indicate $0.8-1 \mathrm{GPa}$ and $700-800^{\circ} \mathrm{C}$ metamorphic conditions (Santallier 1981). The $\mathrm{D}_{2}$,

171 event, characterised by a top-to-the-NW ductile shearing, is widely documented from the

172 southeast Massif Central up to the Southern part of the Massif Armoricain. This deformation

173 is stratigraphically dated as pre-Early Visean (i.e. older than $345 \mathrm{Ma}$ ) by the unconformity

174 recognized in the Brévenne area (e.g. Leloix et al., 1999 and enclosed references, Fig. 1). The

175 age of the syn- $\mathrm{D}_{2}$ MP/MT metamorphism is constrained by ${ }^{40} \mathrm{Ar} /{ }^{39} \mathrm{Ar}$ method on biotite,

176 muscovite and amphibole, and by EPMA on monazite between 360 and $350 \mathrm{Ma}$ (Costa 1989;

177 Leloix et al. 1999; Melleton et al. 2009).

178 The syn-metamorphic $\mathrm{D}_{3}$ deformation is recognized only in the Para-autochthonous

179 Unit of the southern part of the Massif Central that experienced a first deformation at ca 340-

$180335 \mathrm{Ma}$ (Caron 1994; Faure et al. 2005). Further south, south-verging recumbent folds and

181 thrusts of the Paleozoic series dated of Late Visean-Early Namurian ( $c a 325 \mathrm{Ma}$ ) by the syn-

182 orogenic sediments of the foreland basin, are also related to the $\mathrm{D}_{3}$ event. This progressive

183 southward younging of the nappe tectonics is coeval with the development of a flat-lying

184 foliation and a N-S to NE-SW striking stretching lineation. In contrast to the southern part of

185 the Massif Central, in its northern part, the Late Visean deformation develops under brittle

186 conditions. It is represented by a NW-SE stretching, related to the emplacement of NE-SW

187 striking dykes of basalt, dacite, and microgranite in the Tuff Anthracifères series. This

188 deformation is interpreted as the onset of the syn-orogenic extension (Faure 1995).

189 Ductile normal faults, such as Argentat or Nantiat faults, coeval with Serpukhovian-

190 Bashkirian (or Namurian-Westphalian in W. European stratigraphy, i.e. 325-315 Ma) 
191 synkinematic granite emplacement, argue for an extensional tectonic phase named the $\mathrm{D}_{4}$

192 event (Faure 1995). As shown by petrofabric and AMS studies, most of the Late

193 Carboniferous leucogranite and porphyritic monzogranite plutons and their metamorphic

194 aureoles exhibit a well-defined NW-SE trending mineral or stretching lineation (Talbot et al.

195 2005; Joly et al. 2007). The tectonic-plutonic $\mathrm{D}_{4}$ event, widespread in the entire Massif

196 Central, is interpreted as a syn-orogenic extensional process since at this time, compression

197 was still active in the northern and southern outer zones of the Variscan belt, such as Ardenne 198 and Montagne Noire-Pyrénées, respectively.

199 The last phase in the structural evolution of the French Massif Central is a Late

200 Carboniferous (Kasimovian-Ghzelian, or Stephanian) $\mathrm{D}_{5}$ late-orogenic extensional event that

201 is distinguished from the previous one by the NNE-SSW strike of the maximum stretching

202 direction. Intramontane coal basins develop either as half-grabens or left-lateral pull-aparts 203 depending on the strike and kinematics of the bounding fault that controls the basin opening 204 and sedimentary infill.

205

206 The Sioule metamorphic series

207 The bulk architecture

208 Located in the northern part of the French Massif Central, the Sioule metamorphic series is 209 bound to the west by the Late Carboniferous Sillon Houiller sinistral wrench fault, and to the 210 east by the Oligocene Ebreuil and Limagne grabens (Figs. 1, 2). The Tréban Massif and the

$211 \mathrm{~S}^{\text {te }}$-Christine wrench fault are the northern and southern limits of the Sioule metamorphic 212 series, respectively (Fig. 2). The metamorphic series is intruded by two granitic plutons. The 213 Pouzol-Servant porphyritic microgranite is a biotite granite dated at ca $330 \mathrm{Ma}$ (Pin, 1991).

214 The Echassières leucogranite is a small, differentiated, peraluminous pluton dated at $c a 310$

215 Ma (Duthou and Pin 1987; Cheilletz et al. 1992). The Sioule series is a classic example of an 216 inverted metamorphic sequence in the Massif Central (Grolier 1971). Three lithological and 
structural units have been described (Richard 1938; Grolier 1971; Faure et al. 1993). From top

218 to bottom, they are: a) an upper unit composed of biotite-sillimanite gneiss, and biotite-

219 sillimanite \pm cordierite migmatite developed at the expense of the underlying gneiss that

220 enclose a few meter-sized boudins of kyanite-garnet-plagioclase high-pressure granulitic

221 paragneiss partly retrogressed under amphibolite facies conditions (Ravier and Chenevoy

222 1979). This unit is correlated with the Upper Gneiss Unit (UGU) of the French Massif Central

223 (cf section 2); b) an intermediate unit formed by biotite-muscovite-sillimanite-K feldspar-

224 garnet paragneiss corresponding to the Lower Gneiss Unit (LGU), and c) a biotite-staurolite-

225 garnet micaschist that crops out around the Echassières pluton. This unit, which is structurally

226 below the two micas paragneiss of the LGU, lacks of orthogneiss and anatectic melts, it is

227 therefore correlated with the Para-autochthonous Unit (PAU).

Structural outline of the Sioule metamorphic series

230 In the study area, the observed structures, and the related kinematics account well for a

231 multistage tectonic evolution. In agreement with previous works (Grolier 1971; Feybesse and

232 Teygey 1987; Faure et al. 1993; Schulz et al. 2001; Schulz 2009), the foliation is folded by

233 NNW-SSE trending km-scale upright synform and antiform (Fig.2). A WNW-ESE striking

234 stretching and mineral lineation is well developed in the foliation plane of the PAU, LGU, and

235 UGU. Microscope-scale shear criteria, such as sigmoidal micas, asymmetric pressure shadows

236 around feldspar or garnet, and S-shaped inclusion trails in garnet consistently indicate a top-

237 to-the WNW shearing (Faure et al. 1993; Schulz 2009). These microstructural features are

238 relevant to the $\mathrm{D}_{2}$ event of the Massif Central.

239 In the UGU, in addition to the main NW-SE $\mathrm{D}_{2}$ deformation, a NNE-SSW striking

240 mineral and stretching lineation is also recognized (Grolier 1971; Feybesse and Teygey 1987;

241 Faure et al. 1993). This deformation, characterized by elongated biotite-sillimanite 
aggregates, stretched K-feldspar, and axes of intrafolial folds parallel to the stretching lineation, is associated with top-to-the SSW kinematic indicators. A Barrovian-type metamorphism with biotite-sillimanite-K-feldspar assemblage is coeval with this deformation event that appears less developed, and older, than the NW-SE $\mathrm{D}_{2}$ one. In the upper part of the UGU, the biotite-sillimanite \pm cordierite migmatite exhibits also the NNE-SSW mineral and stretching lineation, with similar top-to-the-SW kinematics as those observed in the underlying biotite-sillimanite gneiss. By correlation with the general tectonic-metamorphic pattern of the FMC, this early phase is correlated with the $\mathrm{D}_{1}$ event, thus a Middle Devonian age, dated from 385 to $375 \mathrm{Ma}$ is suggested (Faure et al. 2009) but not documented yet. Furthermore, top-to-the-WNW and top-to-the-ESE shearing, characterized by shear bands cutting through the regional foliation, sericite pressure shadows upon cataclazed staurolite or garnet porphyroclasts, develop around the Echassières pluton. These kinematic indicators, coeval with greenschist facies metamorphic conditions, are related to the emplacement of the Echassière leucogranite pluton in an extensional setting. Thus this deformation phase corresponds to the $\mathrm{D}_{4}$ event (Faure et al. 2009).

In contrast with other areas of the French Massif Central, mafic eclogites formed during the earliest $\mathrm{D}_{0}$ event are not recognized in the Sioule area. Nevertheless, kyanitegarnet-plagioclase-rutile high-pressure granulitic gneiss, garnet-pyroxenite, and rare serpentinite boudins are mapped in the UGU (Grolier 1971; Ravier and Chenevoy 1979). These rocks argue for an early HP event probably equivalent to the $\mathrm{D}_{0}$ one. Moreover, in paragneiss, as shown by the symplectitic texture, these HP garnet and kyanite grains are surrounded by a biotite-sillimanite or muscovite assemblage representative of an amphibolite facies retrogression developed during the $\mathrm{D}_{1}$ or $\mathrm{D}_{2}$ events (Fig. 3). As in most areas of the Massif Central, the planar and linear fabrics related to the $\mathrm{D}_{0}$ event have been erased by subsequent metamorphic recrystallization or deformation events. But since syn- $\mathrm{D}_{0}$ minerals, 
such as kyanite, core of garnet, and possibly monazite are preserved, the rocks may still be suitable to yield the age of the HP event.

Available time constraints in the Sioule metamorphic series are currently limited (Faure et al., 2002; Schulz, 2009). The Late Visean Pouzol-Servant microgranite and the Bashkirian-Moscovian Echassières leucogranite intrude the already metamorphosed and ductilely deformed series, and thus provide the upper time limit for the $\mathrm{D}_{0}, \mathrm{D}_{1}$, and $\mathrm{D}_{2}$ tectono-metamorphic events. $\mathrm{An}{ }^{40} \mathrm{Ar} /{ }^{39} \mathrm{Ar}$ survey has been carried out in the metamorphic units of the Sioule series (Faure et al. 2002). All the minerals, whatever the rock type or the tectonic unit, yielded similar ca 335-330 Ma ages that were interpreted as the Late Visean thermal overprint since these ages are similar, within the errors, to the age of the "Tuffs Anthracifères" event. Thus, the ages of the different pre-Late Visean tectono-metamorphic events in the Sioule series remain presently unknown.

\section{Sampling and petrological description}

Twenty-four samples representative of the different metamorphic assemblages cropping out in the Sioule series have been petrologically studied in order to bring the time constraints on the metamorphic evolution of this series. After detailed microscopic observations, five samples were selected due to their suitable parageneses and textures to ensure the presence of accessory minerals such as monazite and zircon developed during the $\mathrm{D}_{1}$ and $\mathrm{D}_{2}$ tectonometamorphic events. The sample location in the Sioule nappe pile, and the GPS position, are provided in Figure 2 and Table 1, respectively. The PAU is represented by a staurolite-garnet micaschist (SO3) located to the East of the Echassières pluton. The LGU is represented by a two-mica paragneiss (SO17) to the SE of the same pluton. The UGU is represented by a biotite-sillimanite gneiss (SO7), a migmatitic gneiss (SO11), and a biotite-kyanite-garnet paragneiss (SO15), located on both limbs of the antiform. The microstructural descriptions 
292 herein refer to thin sections cut parallel to the stretching lineation (X) and perpendicular to the 293 foliation plane (Z), i.e. in the XZ plane of the finite strain ellipsoid. Sample SO3, belonging to the Para-autochthonous unit, consists of quartz, feldspar,

295 biotite, muscovite, garnet, staurolite, sericite, and chlorite. In the field, structural observations 296 show a low-angle ESE plunging foliation, and a N105E to N115E striking mineral lineation 297 (Fig. 3a2). The foliation cut by shear bands, and sigmoidal quartz veins indicate a top-to-the298 SE sense of shear (Fig. 3a1). Under the microscope, cataclazed garnet and staurolite 299 surrounded by an asymmetric mantle of sericite developed during retrogression of the main 300 assemblage indicate the same sense of shear (Fig 4a). Furthermore, garnet exhibits sigmoidal 301 inclusions of quartz and opaque minerals indicating an earlier foliation. The asymmetry of 302 these inclusions indicates a synkinematic crystallisation of these porphyroblasts during a 303 noncoaxial deformation that is not in agreement with the top-to-the-SE sense of shear, but 304 instead argues for a top-to-WNW sense of shear developed during the $\mathrm{D}_{2}$ event. According to 305 Schulz et al (2001), the thermobarometry from the PAU micaschist indicates a prograde P-T 306 evolution with increasing temperatures from $450^{\circ} \mathrm{C}$ to $600^{\circ} \mathrm{C}$ under slightly increasing 307 pressure from 0.7 to $0.8 \mathrm{GPa}$, followed by a $\mathrm{P}$ and $\mathrm{T}$ decrease indicated by the formation of 308 retrogressive sericite during the decompression. Scan Electron Microscope (SEM) 309 backscattered electron (BSE) observation of sample SO3 reveals the presence of 50 to $100 \mu \mathrm{m}$ 310 sized, homogeneous, monazite grains included into biotite or crystallized along grain 311 boundaries.

312 Sample SO17 is a two-mica paragneiss presenting traces of incipient migmatization 313 belonging to the LGU with a segregation of thick quartz-feldspar and thin biotite and 314 sillimanite layers. The flat lying foliation contains a NW-SE striking mineral and stretching 315 lineation related to the $\mathrm{D}_{2}$ event. The mineral assemblage consists of quartz, feldspar, biotite, 316 muscovite, chlorite, and accessory minerals including sillimanite, Fe-Ti-oxides, and monazite. 
317 Muscovite often presents a clear secondary character, growing without preferred orientation

318 while biotite is partially altered into chlorite in line with a late thermal overprint (Faure et al.

319 2002). Biotite contains large subeuhedral monazite grains of ca 80-120 $\mu \mathrm{m}$ size. Monazite

320 also occurs as $c a 80-100 \mu \mathrm{m}$ euhedral inclusions in biotite or quartz. Despite the existence of

321 these two occurrences, in SEM BSE imaging, the monazite grains exhibit homogeneous

322 internal textures without zoning.

323 Sample SO7 is a biotite-sillimanite migmatitic paragneiss belonging to the UGU

324 collected near Moulin du Bouchet (Fig. 2). This rock is composed of quartz, feldspar, garnet,

325 biotite, muscovite, rare staurolite and fibrolitic sillimanite. Field observations of coarse-

326 grained quartz-feldspar leucosome parallel to the foliation indicate that this rock underwent a

327 limited partial melting. The biotite-sillimanite assemblage defines a pervasive foliation and a

328 N50E striking mineral and stretching lineation that can be assigned to the regional $\mathrm{D}_{1}$

329 deformation. However, as already pointed out by Schulz (2009), the subeuhedral shape of the

330 garnet argues for a static growth after the development of the D1 structures. According to

331 Schulz et al. (2001), the biotite-sillimanite gneiss of Moulin de Bouchet, which is located

332 close to our sample SO7, underwent a prograde metamorphic evolution at low pressure (0.4-

$3330.6 \mathrm{GPa})$ and high temperature $\left(650^{\circ} \mathrm{C}-700^{\circ} \mathrm{C}\right)$. Thus, this biotite-sillimanite paragneiss might

334 have also experienced the $\mathrm{D}_{2}$ event, although typical $\mathrm{D}_{2} \mathrm{NW}$-SE stretching lineation is not

335 observed. In this rock, all the analyzed monazite grains, observed in SEM BSE mode, are

336 homogeneous inclusions in biotite (Fig. 4b).

337 Sample SO11, collected at Pont de Menat (Fig. 2) is a migmatitic paragneiss belonging

338 to the upper part of the UGU. This rock is composed of alternations of coarse-grained quartz-

339 feldspar leucosome and fine-grained biotite-fibrolitic sillimanite-garnet melanosome. Field

340 observation shows the occurrence of a pervasive deformation characterized by a flat-lying

341 foliation and a N120E trending mineral and stretching lineation assigned to the $\mathrm{D}_{2}$ event (Fig. 
3423 c). All the analyzed monazite grains observed in SEM BSE mode are homogeneous

343 inclusions in biotite (Fig. 4c).

344 Sample SO15 is a kyanite-garnet \pm rutile paragneiss coming from Saugères (Fig. 2).

345 This rock is composed of biotite, feldspar, quartz, garnet, and kyanite. Garnet and kyanite are

346 1-5 mm sized clasts included in a well-foliated granoblastic matrix composed of quartz,

347 feldspar, and small biotite flakes (Fig. 3d). The kyanite-garnet assemblage that formed in

348 high-pressure granulite facies underwent an amphibolite facies retrogression as shown by

349 biotite overgrowths around garnet porphyroclasts (Ravier and Chenevoy 1979; Fig. 4d).

350 Monazite inclusions in garnet and in biotite exhibit a core-rim chemical zoning.

\section{Monazite EPMA chemical dating}

353 Analytical method and strategy

Due to its high $\mathrm{U}$ and Th contents, and negligible initial Pb content (Parrish 1990), it is

now well acknowledged that a crystallization (or recrystallization) age can be determined

from monazite on the basis of its chemical composition in $\mathrm{U}$, Th, and $\mathrm{Pb}$ determined by electron probe microanalysis (EPMA). Such a simple and fast technique has been successfully

358 applied to several plutonic or metamorphic rocks (e.g. Suzuki and Adachi, 1991; Montel et al., 1996; Cocherie et al., 1998, 2005; Cocherie and Albarède, 2001; Schulz et al., 2009; Faure

et al., 2010, and enclosed references). Monazite is a common accessory mineral in

metamorphic rocks, especially in metapelites. It crystallizes in a wide range of P-T conditions,

362 from greenschist facies (Cabella et al. 2001; Rasmussen et al. 2001) to amphibolite (Smith

363 and Barreiro 1990; Kohn and Malloy 2004) and granulite facies (Bé Mézème et al. 2006; Mc

364 Farlane and Frost 2009) in rocks metamorphosed under Barrovian P-T gradient during

365 prograde or retrograde paths. Previous studies have shown also that monazite can crystallize

366 in blueschist (Janots et al. 2006) or even eclogite facies (Nagy et al. 2002). Consequently, 
analyzed monazite grains must be linked with petrological studies to delimit their P-T crystallization domain. The chemical composition of monazite is an important parameter in order to discuss the radiometric ages.

In situ chemical U-Th- $\mathrm{Pb}$ dating of monazite has been developed over the past fifteen years allowed by technological progress performed on electron microprobe analyses (EPMA; Suzuki and Adachi 1991; Montel et al. 1996; Cocherie et al. 1998, 2005). The method uses the radiochronometer between $\mathrm{U}$ and $\mathrm{Th}$ parent and $\mathrm{Pb}$ radiogenic elements, considering the restricted lead diffusion in monazite lattice below $900^{\circ} \mathrm{C}$ (Cocherie et al. 1998). The determination of $\mathrm{U}$, Th and $\mathrm{Pb}$ contents can be performed directly by EPMA in situ analyses on polished thin section after textural optical microscope observation of crystallisationdeformation relationships between the constitutive minerals, and monazite internal structure determination using a SEM in BSE mode. This approach provides petrological constraints on the analyzed grains and thus allows us to discuss the significance of the calculated ages in the crystallisation-deformation history of the rock.

SEM BSE was used to define heterogeneous chemical compositional domains of monazite. In metamorphic rocks, contrasted chemical domains can be explained by the superimposition of metamorphic events that record a polyphase evolution during orogenic processes. Theoretical procedure to reduce the data and to calculate the average age from individual spot analyses is given by Cocherie and Albarède (2001), Cocherie et al. (2005), and Cocherie and Legendre (2007). The analysis of monazite grains directly from polished thin sections was performed by a Cameca SX 50 EPMA co-operated by BRGM-CNRS-Orléans University. An accelerating voltage of $20 \mathrm{kV}$, and a beam current of $100 \mathrm{nA}$ were chosen as operating conditions. Synthetic phosphates, glasses and natural minerals were used as standards. The counting times ( $2 / 3$ on peak and $1 / 3$ on background) varies from 20 s for $\mathrm{Si}, \mathrm{P}$, Ca, Nd, Gd, Y, Th, Ce and La, to 100 s for U and 120s for Pb. Considering such parameters, 
392

the detection limit for $\mathrm{Th}, \mathrm{U}$ and $\mathrm{Pb}$ is $150 \mathrm{ppm}$ (Cocherie and Albarede, 2001). X-ray element maps were also recorded with an accelerating voltage of $20 \mathrm{kV}$ and beam current of $100 \mathrm{nA}$, using the wavelength-dispersive spectrometers. Details on the analytical procedure are the same as those used in Cocherie et al. (2005) and Faure et al. (2008, 2010). Age calculations were done using the Isoplot/Ex (2.49) program of Ludwig (2001) and a Microsoft Excel add-in program for determining U-Th-Pb ages from EPMA measurements (Pommier et al. 2002). The $2 \sigma$ errors given on individual ages depend on $\mathrm{U}, \mathrm{Th}$, and $\mathrm{Pb}$ contents, and are calculated by propagating the uncertainties of these elements (at 95\% confidence level).

Because the mean age of an homogeneous age population is directly drived from the isochron plot $\mathrm{Th} / \mathrm{Pb}$ vs $\mathrm{U} / \mathrm{Pb}$, only the uncertainty on these two parameters $(\mathrm{Th} / \mathrm{Pb}$ and $\mathrm{U} / \mathrm{Pb})$ are required to calculate the uncertainty on the mean age.

The strategy followed for this study was to derive time constraints for the monazite included into the foliation forming biotite or in contact with it, in order to settle the crystallisation time of the main foliation. Consequently, we concentrated on subeuhedral to euhedral monazite grains. We focused on the dating of well-defined chemical domains so as not to shuffle different heterogeneous domains that would yield different crystallization periods.

Results

Chemical composition of monazite grains. SEM BSE images reveal chemically homogeneous monazite grains for the four samples SO3, SO7, SO11, and SO17. Conversely, the SO15 kyanite-garnet granulitic paragneiss sample presents zoned monazite grains. This zonation corresponds to a core/rim zonation as described by Bé Mézème et al. (2006), mostly due to the spatial distribution of $\mathrm{U}, \mathrm{Th}$ and $\mathrm{Pb}$. The EPMA analysis allows us to quantitatively characterize the chemical composition of the dated grains. The average $\mathrm{U} / \mathrm{Pb}$ and $\mathrm{Th} / \mathrm{Pb}$ ratio 
417 values, details concerning the number of spot analyses, and analyzed grains are provided in

418 Table 1. Representative monazite chemical compositions with uncertainties for samples SO3,

419 SO7, SO11, SO15, and SO17 are given in Table 2. For the granulitic gneiss (sample SO15),

420 core and rim chemical data have been separated. Monazite chemical data for each samples are

421 plotted in the Monazite $\left(2 \mathrm{REEPO}_{4}\right)$ - Cheralite $\left(\mathrm{CaTh}\left(\mathrm{PO}_{4}\right)_{2}\right)$ - Huttonite $\left(2 \mathrm{ThSiO}_{4}\right)$ diagram

422 (Linthout 2007; Fig. 5a), in order to show the relative substitution between end-member

423 monazite phase and the cheralite or huttonite components (Fig. 5a). The cheralite substitution

424 is always low, as already observed for various metamorphic environments (e.g. Franz et al.

425 1996; Cabella et al. 2001), and huttonite substitution is absent or negligible. In samples SO3,

426 SO7, SO11 and SO17, monazite grains appear as homogeneous domains in BSE images, and

427 the analytical data scatter along the cheralite-monazite axis showing clearly a common

428 substitution. In sample SO15, the analyzed monazite grain is composed of two domains in the

429 BSE images, with a light (i.e. dense) core and a dark (i.e. light) rim. Data plotted in the

430 Monazite $\left(2 \mathrm{REEPO}_{4}\right)$ - Cheralite $\left(\mathrm{CaTh}\left(\mathrm{PO}_{4}\right)_{2}\right)$ - Huttonite $\left(2 \mathrm{ThSiO}_{4}\right)$ diagram (Fig. 5a) show

431 a relatively high Ce-monazite component into the core of the grain (white diamond) and a

432 cheralite enriched rim (black diamond), corresponding to two different chemical domains.

433 The $(\mathrm{Th}+\mathrm{U}+\mathrm{Si}+\mathrm{Pb})=\mathrm{f}(\mathrm{REE}+\mathrm{P})$ plot, modified from Franz et al. (1996), confirms the spread

434 of the analytical data for samples SO3, SO7, and SO11 along the CaThREE -2 axis

435 corresponding to the cheralite substitution (Fig. 5b). Monazite chemical data from the

436 staurolite micaschist SO3 (Fig. 5b) indicate a limited huttonite substitution pointed out by

437 small vertical variation in $\mathrm{Th}+\mathrm{U}+\mathrm{Si}+\mathrm{Pb}$. Chemical data of monazite from biotite-sillimanite

438 gneiss $\mathrm{SO} 7$ and SO11 show a more significant huttonite substitution than for SO3. The core

439 and the rim of dated monazite grain from sample SO15 are characterized by two distinct sets

440 of chemical compositions. The rim is richer in cheralite component than the core, even if

441 huttonite substitution in each domain seems to be similar (Fig. 5b). X-ray maps depicting the 
442 semiquantitative distribution of $\mathrm{Th}, \mathrm{Ca}$, and $\mathrm{U}$ confirm the chemical differences between the

443 core and the rim of SO15 grain (Fig. 5d). These maps show that the monazite rim of monazite

444 is enriched in Th and Ca compared to the core. The $\mathrm{U}$ content is relatively equivalent in the

445 core and rim, except for an enriched fringe in the rim. This domain was not analyzed because

446 of holes on the polished surface. Despite the presence of several small-sized domains

447 indicated by the $\mathrm{Ca}$ and Th contents, the entire core is homogeneous in Th and $\mathrm{U}$

448 composition.

$U-T h-P b$ chemical dating. In this section, the ages of the analyzed monazite grains

451 from samples $\mathrm{SO} 3$, SO 17, SO7, SO11, SO15 are presented following the tectonic order from 452 bottom to top (Fig. 2).

453 Staurolite micaschist SO3. Data points are highly scattered on the $\mathrm{Th} / \mathrm{Pb}$ vs. U/Pb 454 diagram, leading to a small error envelope. The intercept ages are similar within errors, since 455 the $\mathrm{U}-\mathrm{Pb}$ age (intercept with $\mathrm{U} / \mathrm{Pb}$ axis), and the $\mathrm{Th}-\mathrm{Pb}$ age (intercept with $\mathrm{Th} / \mathrm{Pb}$ axis) are at $456379+54 /-62 \mathrm{Ma}$, and 357+26/-23 Ma, respectively. The calculated MSWD of 1.3 indicates 457 that the population of 73 analyses is statistically homogeneous within the analytical errors 458 (Wendt and Carl 1991). As a consequence, it is possible to calculate the mean age at the 459 centroid where the precision is the best within the error envelope. Thus, the monazite grains 460 yield a mean age of $363 \pm 8 \mathrm{Ma}$ (at $2 \sigma$ confidence level; Fig. $6 a$ ).

461 Two-mica gneiss (SO17). Data points are weakly scattered on the $\mathrm{Th} / \mathrm{Pb}$ vs. U/Pb 462 diagram, leading to a large error envelope. The intercept ages are similar within errors, since 463 the intercept $\mathrm{U}-\mathrm{Pb}$ age and the intercept $\mathrm{Th}-\mathrm{Pb}$ age are at $399+44 /-53 \mathrm{Ma}$, and 328+31/-26 464 Ma, respectively. The calculated MSWD of 0.63 indicates that the population of 38 analyses 465 is statistically homogeneous within the analytical errors (Wendt and Carl 1991). As a 466 consequence, it is possible to calculate the mean age at the centroid where the precision is the 
467 best within the error envelope. Thus, the monazite grains yield a mean age of $351 \pm 5 \mathrm{Ma}$ (at $4682 \sigma$ confidence level; Fig. $6 b)$.

Biotite-sillimanite gneiss (SO7). Data points are relatively scattered on the $\mathrm{Th} / \mathrm{Pb}$ vs.

$470 \mathrm{U} / \mathrm{Pb}$ diagram, leading to a small error envelope. The intercept ages are similar within errors,

471 since the intercept $\mathrm{U}-\mathrm{Pb}$ age and the intercept $\mathrm{Th}-\mathrm{Pb}$ age are at 331+39/-46 $\mathrm{Ma}$, and 371+33/-

$47228 \mathrm{Ma}$, respectively. The calculated MSWD of 1.19 indicates that the population of 73

473 analyses is statistically homogeneous within the analytical errors (Wendt and Carl 1991) and

474 as a consequence, it is possible to calculate the mean age at the centroid. Thus, the monazite

475 grains yield a mean age of $355 \pm 7 \mathrm{Ma}$ (at $2 \sigma$ confidence level; Fig. $6 \mathrm{c}$ ).

476

Migmatitic gneiss (SO11) of Pont de Menat. Data points on the Th/Pb vs. $\mathrm{U} / \mathrm{Pb}$

477 diagram are less scattered than for previous sample, which may lead to a larger error envelop.

478 However, the large number of analyses $(n=174)$ decreases the envelop size. The intercept

479 ages are similar within errors, since the intercept U-Pb age and the intercept $\mathrm{Th}-\mathrm{Pb}$ age are at $480342+45 /-51 \mathrm{Ma}$, and 373+24/-21 Ma, respectively. The calculated MSWD of 0.98 indicates

481 that the population of 174 analyses is statistically homogeneous within the analytical errors

482 (Wendt and Carl 1991). As a consequence, it is possible to calculate the mean age at the

483 centroid. Thus, the monazite grains yield a mean age of $363 \pm 4 \mathrm{Ma}$ (at $2 \sigma$ confidence level;

484 Fig. 6d).

485 Kyanite-garnet granulitic paragneiss (SO15) of Saugères. Monazite in sample SO15

486 exhibits a core-rim zonation of the grain, and in consequence, EPMA data were processed

487 separately for the different domains in order to calculate two isochron ages. 47 and 21

488 analyses were performed in the core and rim of a single grain, respectively. The 47 analyses

489 from the core on the $\mathrm{Th} / \mathrm{Pb}$ vs. $\mathrm{U} / \mathrm{Pb}$ diagram are clustered, leading to a large error envelope.

490 The intercept ages are similar within errors, since the intercept U-Pb age and the intercept Th-

$491 \mathrm{~Pb}$ age are at 517+281/-322 Ma, and 390+81/-57 Ma, respectively. The calculated MSWD of 
4921.15 indicates that the population of the 47 analyses is statistically homogeneous within the

493 analytical errors (Wendt and Carl 1991). As a consequence, it is possible to calculate a mean

494 age at the centroid. Thus, the core of this monazite grain yields a mean age of $416 \pm 15 \mathrm{Ma}$ (at $4952 \sigma$ confidence level; Fig. 6e).

496 Moreover, the 21 analyses performed from the monazite rim are well-scattered, 497 leading to a small error envelope. The intercept ages are similar within errors, since the 498 intercept $\mathrm{U}-\mathrm{Pb}$ age and the intercept $\mathrm{Th}-\mathrm{Pb}$ age are at 423+74/-88 Ma, and 338+36/-30 Ma, 499 respectively. The calculated MSWD of 0.93 indicates that the population of 21 analyses is 500 statistically homogeneous within the analytical errors (Wendt and Carl 1991). As a

501 consequence, it is possible to calculate the mean age at the centroid where the precision is the 502 best within the error envelope. Thus, the monazite grains yield a mean age of $362 \pm 14 \mathrm{Ma}$ (at $5032 \sigma$ confidence level; Fig. 6f).

\section{Zircon U-Pb SIMS dating}

506 Analytical procedure

507 Zircon concentrates were separated from a $\mathrm{ca} 5 \mathrm{~kg}$ of the granulitic paragneiss sample SO15 508 using standard density and magnetic separation techniques. Zircon grains, together with 509 standard zircons TEMORA 2, 91500, and an in-house standard zircon Qinghu, were mounted 510 in an epoxy mount that was then ground and polished to section the crystals in half for 511 analysis. Zircons were imaged with transmitted and reflected light photomicrographs as well 512 as cathodoluminescence (CL) to reveal their internal structures, and the mount was vacuum513 coated with high-purity gold prior to SIMS analyses. Measurements of $\mathrm{U}$, Th and $\mathrm{Pb}$ isotopes 514 were conducted using a Cameca IMS 1280 SIMS at the Institute of Geology and Geophysics, 515 Chinese Academy of Sciences in Beijing. Analytical procedures are similar to those reported 516 by $\mathrm{Li}$ et al. (2009). The primary $\mathrm{O}_{2}{ }^{-}$ion beam spot is about $20 \times 30 \mu \mathrm{m}$ in size. Positive 
517 secondary ions were extracted with a $10 \mathrm{kV}$ potential. In the secondary ion beam optics, a 60

$518 \mathrm{eV}$ energy window was used, together with a mass resolution of $c a 5400$ (at $10 \%$ peak

519 height), to separate $\mathrm{Pb}^{+}$peaks from isobaric interferences. A single electron multiplier was

520 used in ion-counting mode to measure secondary ion beam intensities by peak jumping mode.

521 Analyses of the standard zircon TEMORA 2 were interspersed with unknown grains. Each

522 measurement consists of 7 cycles. $\mathrm{Pb} / \mathrm{U}$ calibration was performed relative to zircon standard

523 TEMORA $2\left({ }^{206} \mathrm{~Pb} /{ }^{238} \mathrm{U}\right.$ age $=417 \mathrm{Ma}$, Black et al. 2004); $\mathrm{U}$ and Th concentrations were

524 calibrated against zircon standard $91500(\mathrm{Th}=29 \mathrm{ppm}$, and $\mathrm{U}=81 \mathrm{ppm}$, Wiedenbeck and

525 Allen 1995). Measured compositions were corrected for common $\mathrm{Pb}$ using non-radiogenic

$526{ }^{204} \mathrm{~Pb}$, and an average of crustal composition (Stacey and Kramers 1975) was used for the

527 common $\mathrm{Pb}$. Data reduction was carried out using the Isoplot/Ex v. 2.49 program (Ludwig

528 2001). In order to monitor the external uncertainties of SIMS U-Pb zircon measurements, an

529 in-house standard zircon Qinghu was alternately analyzed as an unknown together with other

530 unknowns. Twenty measurements on Qinghu zircon (Table 3) yield a Concordia age of $160 \pm$

$5311 \mathrm{Ma}(2 \mathrm{SE}, \mathrm{MSWD}$ of concordance $=0.92)$, which is in good agreement within errors with

532 the recommended $\mathrm{U}-\mathrm{Pb}$ age of $159.5 \pm 0.2 \mathrm{Ma}$ ( $\mathrm{Li}$ et al. 2009). Zircon $\mathrm{U}-\mathrm{Pb}$ age data are

533 presented in Table 3.

535 Results

536 Fifty-five zircon grains from the SO 15 granulitic paragneiss have been analyzed (Table 3).

537 All but four zircons are concordant within analytical uncertainties (discordance degree $<4 \%$ ).

538 The dated zircons can be divided into two groups in terms of their morphological feature, ages

539 and Th/U ratio. In group 1, zircons are mostly sub-rounded to multifaceted grains and yield

540 ages between 324 and 349 Ma. They are characterized by low Th/U ratio $(<0.1)$ and faint CL

541 luminescence (Table 3, Fig. 7), similar to metamorphic zircons (Corfu et al. 2003). Contrarily, 
542 Group 2 zircons are dated between $368 \mathrm{Ma}$ and $1.99 \mathrm{Ga}$ (Table 3). They are mostly oval

543 shaped grains showing concentric zoning under CL (Fig. 7), and relatively high Th/U ratio

544 (mostly >0.1), similar to the magmatic zircons (Corfu et al. 2003). Among them, four zircons

545 (spots @ 06, 26, 27 and 37) are highly discordant, with ${ }^{207} \mathrm{~Pb} /{ }^{206} \mathrm{~Pb}$ ages between 1629 and

$5461994 \mathrm{Ma}$. On the probabilistic histogram of U-Pb ages for 51 concordant analyses (Fig 8),

547 Group 1 zircons form one major peak at $342 \mathrm{Ma}(\mathrm{n}=24)$ and a subordinate peak at $327 \mathrm{Ma}(\mathrm{n}$

$548=6$ ), corresponding to Concordia age of $343 \pm 2 \mathrm{Ma}$ and $328 \pm 4 \mathrm{Ma}$, respectively, on a U-Pb

549 Concordia plot (Fig. 9). Thus, Group 1 zircons are most likely metamorphic in origin. The

550 remaining 21 Group 2 zircons display a scattered age pattern ranging from 370 to $800 \mathrm{Ma}$,

551 which might be detritus zircons of magmatic origin with or without later metamorphic and

552 hydrothermal overprinting.

553

\section{Discussion}

555 Many studies have pointed out the relationships between the age and the chemical

556 composition of monazite grains in polymetamorphic terranes (e. g. Martins et al., 2009; Kelly

557 et al., 2012). In samples SO3, SO7, SO11 and SO17, SEM BSE images of monazite grains

558 revealed homogeneous grains. The chemical compositions of the analysed monazite grains

559 cluster near the Monazite-(Ce) pole and scatter along the cheralite axis (Fig. 5a and b). The

560 weak data dispersal along the cheralite substitution line indicates that the analysed grains

561 represent a rather homogeneous population. Monazite grains from sample SO15 that exhibit a

562 light (i.e. dense) core and a dark (i.e. light) rim in BSE images, are scattered between the

563 cheralite $\left(\mathrm{CaTh}\left(\mathrm{PO}_{4}\right)_{2}\right)$ and huttonite $\left(2 \mathrm{ThSiO}_{4}\right)$ substitutions (Fig. 5b). Compared with the

564 other analysed samples, such a difference is explained by a high REE (La, Ce, Pr, Nd) content

565 and absence of $\mathrm{Y}$ in the core of monazite grains from sample SO15 (Table 2). The analysed

566 spots in both the core and rim parts delimit two clusters with different chemical composition. 
It is noteworthy that i) the chemistry of the SO15 monazite rim is close to the chemistry of the other analysed monazite grains, and ii) the reaction leading to the rim crystallisation occurred contemporaneously to the crystallisation of the other monazite grains in samples $\mathrm{SO}$, $\mathrm{SO}$,

SO11 and SO17. Datings carried out in this study have been made on grain populations with homogeneous chemical composition that make us confident about the age interpretation. The kyanite-garnet granulitic gneiss SO15 preserves a core domain within monazite yielding a ca $415 \mathrm{Ma}$ age. This Early Devonian age can be assigned to the $\mathrm{D}_{0}$ event recognized in the UGU in several places in the Massif Central (Pin and Peucat 1986; Pin and Vielzeuf 1988; Paquette et al. 1995). All the dated samples, whatever the tectonic unit to which they belong, yielded similar within the error, monazite U-Th-Pb ages at $c a$ 365-350 Ma 577 (Fig. 10). Since they share common structural features, including a similar NW-SE striking, $578 \mathrm{D}_{2}$, stretching lineation, which is well developed in samples SO3, SO11, SO17, and SO15, the 363-351 Ma ages yielded by the monazite in these rocks can be attributed to the $\mathrm{D}_{2}$ tectonometamorphic event. Similar ages were already reported for the $\mathrm{D}_{2}$ tectono-metamorphic event in other areas of the French Massif Central, such as the Lot series (Costa 1989) or Limousin

582 (Melleton et al. 2009). Moreover, these ages are consistent, within the errors, with the 583 emplacement age of the Guéret and $S^{t}$-Gervais d'Auvergne plutons (Figs 1,2) that exhibit a 584 NW-SE striking magmatic lineation (Faure et al. 2005; Cartannaz et al. 2007). These plutons, dated at 360-350 Ma, emplaced at the end of the $\mathrm{D}_{2}$ event (Berthier et al. 1979; Cartannaz et al. 2007; Faure et al., 2009). The SO11 $\mathrm{D}_{1}$ migmatite sample, deformed during the $\mathrm{D}_{2}$ event,

587 yields also a monazite $\mathrm{U}-\mathrm{Th}-\mathrm{Pb}$ age at $\mathrm{ca} 363 \mathrm{Ma}$, which is consistent with the Late

588 Devonian-Early Carboniferous age of the $\mathrm{D}_{2}$ event.

It is worth to note that although the $\mathrm{D}_{1}$ migmatization is preserved in samples SO11, and SO7, the P-T conditions of 0.4-0.6 GPa and $550-600^{\circ} \mathrm{C}$, calculated in the UGU from a 
592 the $\mathrm{D}_{1}$ event, as defined in other areas of the French Massif Central (e.g. Santallier 1981;

593 Mercier et al. 1991; Lardeaux et al. 2001; Bellot and Roig 2007), but instead represent a low 594 pressure-medium temperature event similar to the $\mathrm{D}_{2}$ one as observed in the Limousin, Lot or 595 Rouergue areas (Duguet et al. 2006; Bellot and Roig 2007; Melleton et al 2009). Thus this 596 biotite-sillimanite paragneiss might have also experienced the $\mathrm{D}_{2}$ event, even if the typical

597 NW-SE $D_{2}$ stretching lineation is not observed in this rock. Furthermore, the NE-SW striking $598 \mathrm{D}_{1}$ mineral lineation is clearly observed in sample SO17. In these three rocks, the analyzed 599 monazites do not record the Devonian migmatization dated between $385 \mathrm{Ma}$ and $375 \mathrm{Ma}$ in 600 Lyonnais (Duthou et al. 1994), Limousin (Faure et al. 2008) and S. Brittany (Cocherie et al. 601 2005). This result can be variously interpreted. Firstly, monazite was unable to crystallize 602 under the $\mathrm{D}_{1}$ metamorphic conditions; secondly, monazite effectively crystallized, but it may 603 have been dissolved during the HT event, and then neocrystallized in biotite during the 604 prograde $\mathrm{D}_{2}$ event; thirdly, due to the limited number of analyzed grains, our sampling missed 605 any monazite grain formed during the $\mathrm{D}_{1}$ event. Though the first hypothesis appears unlikely, 606 since aluminous composition protoliths are suitable for monazite crystallization, the other two 607 explanations cannot be discarded. Thus, the 365-350 Ma monazite ages obtained from 608 samples SO3, SO17, SO7, SO11, and the monazite rim from sample SO15 are attributed to 609 the neocrystallization or the complete recrystallization of monazite during the $\mathrm{D}_{2}$ event, 610 leading to the total loss of any early monazite. In order to get a better understanding of the 611 thermo-barometric and chemical conditions that allow monazite crystallization or dissolution

612 with respect to other phases such as garnet and biotite, a detailed analysis of the chemical 613 elements exchanges during the succession of the crystallization-deformation events would be 614 necessary. On the contrary to Limousin or Maures areas (e. g. Duguet et al. 2006; Bellot and 615 Roig 2007; Oliot et al. 2015), such a study is not available yet for the Sioule metamorphic 616 series. 
Besides, zircon from the granulitic paragneiss yields U-Pb SIMS ages younger than the monazite ones at $343 \pm 2 \mathrm{Ma}$, and $328 \pm 2 \mathrm{Ma}$. The latest is close to the whole-rock $\mathrm{Rb} / \mathrm{Sr}$ age of the Pouzol-Servant microgranite at 330 Ma (Duthou and Pin 1987; Pin 1991), and also to the cooling ages yielded by the ${ }^{40} \mathrm{Ar} /{ }^{39} \mathrm{Ar}$ analyses on biotite, muscovite and amphibole for

621 the entire nappe-stack of the Sioule metamorphic series, either in the Upper Gneiss, Lower 622 Gneiss, and Para-autochthonous Units (Faure et al. 2002; Fig. 11). As pointed out in the 623 "Geological Setting" section, the ca 330 Ma age is that of the "Tufs anthracifères" magmatism widespread in the northern part of the French Massif Central (Fig. 11). The ${ }^{40} \mathrm{Ar} /{ }^{39} \mathrm{Ar}$ ages of the Sioule metamorphic rocks, younger than the Late Visean unconformity, have been interpreted as a thermal reset provided by the high heat flux during the onset on the extensional tectonics in the northern part of the French Massif Central. Thus we suggest here that the zircon age at $328 \pm 4$ Ma Ma might be due to recrystallizations processes, possibly assisted by hydrothermal fluids, also as a consequence of the Late Visean thermal reset. Indeed, the LGU and PAU rocks exhibit several evidence of retrogression such as chlorite

631 developed at the expense of biotite, sericite surrounding staurolite, (Fig 4a) and albite

632 overprinting the foliation. These minerals argue for a late metamorphic stage associated with

633 fluid circulation. In the present state of knowledge, detailed petrological investigations to 634 characterize this hydrothermal event are not available. The $343 \pm 2 \mathrm{Ma}$ age yielded by 24 635 zircon grains is more difficult to interpret in the geological framework. This age 636 corresponding to the majority of analyzed concordant grains is different, within the error, 637 from the $328 \pm 4$ Ma age. Furthermore, such a Middle Visean age is rarely reported in the 638 northern part of the Massif Central. However, to the East of the study area, in the Lyonnais, 639 syn-kinematic granites emplaced along a NE-SW striking dextral strike-slip fault yield biotite 640 and muscovite ${ }^{40} \mathrm{Ar} /{ }^{39} \mathrm{Ar}$ ages at ca $346 \pm 3 \mathrm{Ma}$ and $349 \pm 3 \mathrm{Ma}$, respectively (Costa et al. 1993). 
$642 S^{\text {te }}$-Christine dextral strike slip fault develops in the southern boundary of the Sioule series

643 (Fig. 2). One possible interpretation would be to relate this ca $343 \mathrm{Ma}$ (i. e. Middle Visean)

644 age to fluid circulations coeval with a transcurrent shearing event too. Importantly, the zircon

645 SIMS measurement did not recorded the 365-350 Ma $\mathrm{D}_{2}$ ages.

646 Previous monazite U-Th/Pb ages (Schulz 2009) range between $343 \mathrm{Ma}$ and $327 \mathrm{Ma}$,

647 i.e. much younger than those reported in this study. These dates were attributed to two distinct 648 events, in agreement with the ${ }^{40} \mathrm{Ar} /{ }^{39} \mathrm{Ar}$ ages (Faure et al. 2002), the monazite chemical ages 649 younger than $340 \mathrm{Ma}$ were considered as due to the Late Visean hydrothermal event related to 650 the "Tufs anthracifères" magmatism. Conversely, ages older than 340 Ma were considered as 651 minimum ones associated to a top-to-the-SE tectonic event. However, structural 652 investigations demonstrated that the top-to-the-SE shearing was coeval with the emplacement 653 of the Echassières pluton at ca $310 \mathrm{Ma}$ (Feybesse and Teygey 1987; Faure et al. 1993). The 654 discrepancy between our results and the previous ages by Schulz (2009) can also be explained 655 considering the data reduction method. The previous study uses frequency histograms to 656 process the analytical data associated with very large, routinely $c a 15 \mathrm{Ma}$, errors. Moreover, 657 the frequency diagram method provides a mean age systematically younger than the one given 658 by the $\mathrm{Th} / \mathrm{Pb}=\mathrm{f}(\mathrm{U} / \mathrm{Pb})$ isochron method (Cocherie and Albarède 2001). For example, the 659 weighted average age computed here for the monazite core and rim of sample SO15 (Fig. 5c) 660 also yields ages at $392 \pm 16 \mathrm{Ma}$, and 359 $\pm 18 \mathrm{Ma}$ younger than $416 \pm 8 \mathrm{Ma}$, and $362 \pm 14 \mathrm{Ma}$ 661 yielded by the isochron method. In addition, the results provided by the isochron method are 662 generally closer to the ICP-MS isotopic measurements than those provided by the histogram 663 method (Cocherie et al. 1998; Cocherie and Albarède 2001), and thus are preferred here. As 664 mentionned in the "Sioule metamorphic series" section, in the study area, two pre-Late Visean 665 events, namely $D_{1}$ and $D_{2}$, are recognized. However, the age of the $D_{1}$ and $D_{2}$ range between 
666

667

668

669

670

671

672

673

674

675

676

677

678

679

680

681

682

683

684

685

686

687

688

689

690

385-375 Ma and 360-350 Ma, respectively. Therefore, the ca 340 Ma monazite ages cannot be ascribed to a single tectono-metamorphic event.

Our new monazite chemical ages can be used to place time constraints in the pressure (P)-temperature $(\mathrm{T})$ plot in order to settle the P-T-t paths experienced by each unit. P-T estimates from the Sioule area (Schulz et al. 2001) are consistent with P-T conditions from other areas of the Massif Central (e.g. Santallier 1981; Mercier et al. 1991; Lardeaux et al. 2001; Bellot and Roig 2007; Faure et al. 2008). The UGU, LGU, and PAU underwent different P-T paths depending on their location in the French Massif Central. In the Lyonnais area, the coesite bearing eclogite argue for P conditions about 2.7-2.8 GPa (Lardeaux et al. 2001) whereas such ultra-high pressure conditions are not recorded (or not preserved) in the Sioule area. On the basis of petrological studies in the Limousin and Artense areas (Santallier 1981, Mercier et al. 1991), peak-conditions of $c a 2 \mathrm{GPa}$ for $c a 800^{\circ} \mathrm{C}$ are inferred for the Sioule granulite (Fig. 12). Sample SO15 places a time constraint at ca $415 \mathrm{Ma}$ on this HP event. On the contrary, in the Limousin area, the LGU reached a maximum P value of 1.1-1.2 GPa for $500{ }^{\circ} \mathrm{C}$ (Bellot and Roig 2007; Faure et al. 2008). During their exhumation, the UGU and LGU followed nearly isothermal decompression paths coeval with migmatization, and subsequent cooling during the $\mathrm{D}_{1}$ event at $385-375 \mathrm{Ma}$. The minimum P-T conditions experienced by the UGU and LGU during this eo-Variscan cycle are not precisely settled. Since andalusite replacing sillimanite or kyanite is never observed in the UGU or LGU, we assume that the two units were not exhumed close to the surface but remained burried in the upper crust, even if aluminosilicates might have remained stable during exhumation.

687 Conversely, the PAU never experienced the $\mathrm{D}_{1}$ metamorphism nor migmatization. This unit records maximum $\mathrm{P}$ and $\mathrm{T}$ values of $0.7-0.8 \mathrm{GPa}$, and $500-600^{\circ} \mathrm{C}$, respectively. Our monazite age of sample SO3 at $363 \pm 8$ Ma constrains the age of the MP/MT metamorphism coeval with the top-to-the-NW $\mathrm{D}_{2}$ event. During the same late Devonian-Early Carboniferous period, the 
691 UGU and LGU experienced a second metamorphic cycle leading to maximum P-T conditions

692 of $0.7-0.8 \mathrm{GPa}$, and $500-600^{\circ} \mathrm{C}$ similar to those of the PAU. Our monazite U-Th-Pb ages at 693 362Ma, $363 \mathrm{Ma}, 355 \mathrm{Ma}$, and $351 \mathrm{Ma}$, for samples SO10, SO11, SO7, and SO17,

694 respectively represent the age of the $\mathrm{D}_{2}$ event recorded in the UGU and LGU (Fig. 12).

695 After the completion of the two Variscan metamorphic cycles, the Sioule metamorphic

696 series, like most of the areas in the northern part of the FMC, experienced a huge late

697 orogenic magmatic episode, at ca 335-330 Ma, represented both by deep seated plutonism,

698 dyke emplacement, and aerial volcanism. As already proposed to account for the ${ }^{40} \mathrm{Ar} /{ }^{39} \mathrm{Ar}$

699 ages, the hydrothermalism was responsible for the complete resetting of the zircon $\mathrm{U}-\mathrm{Pb}$

700 isotopic systems during the Tufs Anthracifères event but the U-Th-Pb chronometer was not

701 affected by this late thermal event.

702

\section{Conclusion}

704 This geochronological study in a key area of the Variscan French Massif Central, casts light

705 on the importance of structural and petrological constraints when dealing with age

706 determination of thermal, tectonic and metamorphic events in orogens. These new radiometric

707 ages yielded by monazite and zircon included in the macroscopic foliation allow us to place

708 time constraints on the succession of superimposed deformation and related metamorphic

709 events in the Sioule area. The early Variscan HP/HT D $\mathrm{D}_{0}$ event occurred at $416 \pm 15 \mathrm{Ma}$ and the

$710 \mathrm{MP} / \mathrm{MT} \mathrm{D}_{2}$ event, coeval with the top-to-the NW shearing took place between $365 \mathrm{Ma}$ and

$711350 \mathrm{Ma}$. On the contrary, the $\mathrm{ca} 380 \mathrm{Ma} \mathrm{D}_{1}$ event has not been recorded by monazite. Our

712 study emphasizes that radiometric ages must be carefully discussed in the light of the regional

713 geological setting. Particularly, the knowledge of the thermo-barometric and hydrothermal

714 processes must be a pre-requisite for the understanding of the geochronological data. 
717 Field, and analytical expenses for this study have been supported by the French national 718 program "Carte géologique de la France au 1/50 000" led in BRGM, and by a National 719 Natural Science Foundation of China (NNSFC) grant 41273070. Ida di Carlo and Olivier

720 Rouer are acknowledged for their help for the acquisition of SEM and EPMA analyses. Jean721 Marc Lardeaux and Emilien Oliot are thanked for their constructive reviews.

\section{References}

Bé Mézème E, Cocherie A, Faure M, Legendre O, Rossi P (2006) Electron microprobe monazite geochronology: a tool for evaluating magmatic age domains. Examples from the Variscan French Massif Central. Lithos 87: 276-288

727

Bellot J-P, Roig J-Y (2007) Episodic exhumation of HP rocks inferred from structural data and P-T paths from the southwestern part Massif Central (Variscan belt, France). J Struct

Geol 29: 1538-1557

Berger J, Féménias O, Ohnenstetter D, Bruguier O, Plissart G, Mercier JC, Demaiffe D (2010) New occurrence of UHP eclogites in Limousin (French Massif Central): Age, tectonic setting and fluid-rock interactions. Lithos 118: 365-382.

Berthier F, Duthou JL, Roques M, (1979) Datation géochronologique Rb/Sr sur roches totales

737 du granite de Guéret (Massif central). Âge fini-Dévonien de mise en place de l'un de ses 738 faciès types. Bull. Bur. Rech. Geol. Min. I : 31-42.

740 Black LP, Kamo SL, Allen, CM, Davis D, Aleinikoff JN, Valley JW, Mundil R, Campbell IH,

741 Korsch RJ, Williams IS, Foudoulis C (2004) Improved ${ }^{206} \mathrm{~Pb} /{ }^{238} \mathrm{U}$ microprobe geochronology 
742 by the monitoring of a trace-element-related matrix effect; SHRIMP, ID-TIMS, ELA-ICP-MS

743 and oxygen isotope documentation for a series of zircon standards. Chemical Geology 205 :

$744 \quad 115-140$

745

746 Boutin R, Montigny R, (1993) Datation ${ }^{39} \mathrm{Ar} /{ }^{40} \mathrm{Ar}$ des amphibolites du complexe leptyno747 amphibolique du plateau d'Aigurande : collision varisque à 390 Ma dans le Nord-Ouest du

748 Massif central français. C. R. Acad. Sci. Paris Ser. II 316 : 1391-1398

749

750 Bruguier O, Becq-Giraudon JF, Bosch D, Lancelot JR, (1998) Late Visean (Upper

751 Missisipian) hidden basins in the internal zones of the Variscan Belt: U-Pb zircon evidence

752 from the French Massif Central. Geology 26 : 627-630

753

754 Cabella R, Lucchetti G, Marescotti P (2001) Authigenic monazite and xenotime from pelitic

755 metachert in pumpellyite-actinolite facies conditions, Sestri-Voltaggio zone, Central Liguria,

756 Italy. The Canadian Mineralogist $39: 717-727$

757

758 Caron C, (1994) Les minéralisations Pb-Zn associées au Paléozoïque inférieur d'Europe

759 méridionale. Traçage isotopique $\mathrm{Pb}-\mathrm{Pb}$ des gîtes de l'Iglesiente (SW Sardaigne) et des

760 Cévennes et évolution de socle encaissant par la géochronologie U-Pb, ${ }^{40} \mathrm{Ar}-{ }^{39} \mathrm{Ar}$ et $\mathrm{KAr}$

761 Thèse, Univ. Montpellier, 288 pp

762

763 Cartannaz C, Rolin P, Cocherie A, Marquer D, Legendre O, Fanning C M, Rossi P (2007)

764 Characterization of wrench tectonics from dating of syn- to post-magmatism in the

765 northwestern French Massif Central. Int J Earth Sci 96 : 271-287

766 
767 Cheilletz A, Archibald DA, Cuney M, Charoy B (1992) Ages ${ }^{40} \mathrm{Ar} /{ }^{39} \mathrm{Ar}$ du leucogranite à 768 topaze-lépidolithe de Beauvoir et des pegmatites sodomithiques de Chédeville (Nord du 769 Massif Central, France). Compte Rendus Acad Sci Paris 315 : 329-336

770

771 Cocherie A, Albarède F (2001) An improved U-Th-Pb age calculation for electron

772 microprobe dating of monazite. Geochimica Cosmochimica Acta 65 : 4509-4522 773

774 Cocherie, A., Legendre O (2007) Potential minerals for determining U-Th-Pb chemical age 775 using electron microprobe. Lithos $93: 288-309$

776

777 Cocherie A, Legendre O, Peucat J J, Kouamelan AN (1998) Geochronology of

778 polygenetic monazites constained by in situ electron microprobe $\mathrm{Th}-\mathrm{U}-$ total $\mathrm{Pb}$ 779 determination: implications for lead behaviour in monazite. Geochimica Cosmochimica 780 Acta $62: 2475-2497$

781

782

Cocherie A, Bé Mézème E, Legendre O, Fanning M, Faure M, Rossi P (2005) Electron microprobe dating as a tool for understanding closure of $\mathrm{U}-\mathrm{Th}-\mathrm{Pb}$ system in monazite from migmatite. Am Mineralogist 90 : 607-618

785

786

Cocks LRM (2000) The Early Paleozoic geography of Europe. J Geol Soc London 157: 1-10 787

Corfu F, Hanchar JM, Hoskin PWO, Kinny P (2003) Atlas of Zircon Textures. In: Hanchar, 789 J.M., Hoskin, P.W.O. (Eds.), Zircon. Reviews in Mineralogy and Geochemistry 53: 469-500. 
792 Costa S, (1989) Age radiométrique 40Ar/39Ar du métamorphisme des séries du Lot et du

793 charriage du groupe leptyno-amphibolique de Marvejols (Massif central français), C. R. Acad.

794 Sci. Paris Ser. II 309 : 561-567

795

796 Costa S, Maluski S, Lardeaux J-M (1993) ${ }^{40} \mathrm{Ar} /{ }^{39} \mathrm{Ar}$ chronology of Variscan tectono-

797 metamorphic events in an exhumed crustal nappe: the Monts du Lyonnais complex (Massif

798 Central, France). Chemical Geology 105: 339-359

799

800 Costa S, Maluski S (1988) Datations par la méthode ${ }^{40} \mathrm{Ar} /{ }^{39} \mathrm{Ar}$ de matériel magmatique et

801 métamorphique paléozoïque provenant du forage de Couy-Sancerre (Cher, France)

802 Programme GPF. C R Acad Sci Paris Ser II $306: 351-356$

803

804 Duguet M, Le Breton N, Faure M (2006) P-T paths reconstruction of a collisional event: the 805 example of the Thiviers-Payzac Unit in the Variscan French Massif Central Lithos 98 : 210$806 \quad 232$

807

808 Duthou JL, Cantagrel JM, Didier J, Vialette Y (1984) Paleozoic granitoids from the French

809 Massif Central: age and origin studied by ${ }^{87} \mathrm{Rb} /{ }^{87} \mathrm{Sr}$ system. Phys Earth Planet Int 35: 131-144 810

811 Duthou JL, Pin C (1987) Etude isotopique Rb-Sr de l'apex granitique d'Echassières. Géologie 812 de la France $2: 63-67$

813

814 Duthou JL, Chenevoy M, Gay M (1994) Age Rb/Sr Dévonien moyen des migmatittes à

815 cordiérite du Lyonnais (Massif central français). Comptes Rendus

816 de l'Académie des Sciences $319: 791-796$ 
818 Faure M, Grolier J, Pons J (1993) Extensional ductile tectonics of the Sioule metamorphic

821 Faure M (1995) Late orogenic Carboniferous extensions in the Variscan French Massif

822 Central. Tectonics $14: 132-153$.

823

824 Faure M, Leloix C, Roig JY, (1997) L'évolution polycyclique de la chaîne hercynienne. Bull. 825 Soc. Geol. France 168: 695-705

826

827 Faure M, Monié P, Maluski H, Pin C, Leloix C (2002) Late Visean thermal event in the 828 northern part of the French Massif Central. New ${ }^{40} \mathrm{Ar} /{ }^{39} \mathrm{Ar}$ and $\mathrm{Rb}-\mathrm{Sr}$ isotopic constraints on 829 the Hercynian syn-orogenic extension. Int. J. Earth Sciences 91: 53-75

830

831 Faure M, Bé Mézème E, Duguet M, Cartier C, Talbot J-Y (2005) Paleozoic tectonic evolution 832 of Medio-Europa from the example of the French Massif Central and Massif Armoricain. $\mathbf{J}$ 833 Virtual Explorer Electronic edition ISSN 1441-8142, 19 paper 5.

835 Faure M, Bé Mézème E, Cocherie A, Rossi P, Chemenda A, Boutelier D (2008) Devonian 836 geodynamic evolution of the Variscan Belt, insights from the French Massif Central and 837 Massif Armoricain. Tectonics 27: TC2008, http://dx.doi.org/10.1029/2007TC002115

839 Faure M, Lardeaux JM, Ledru P (2009) A review of the pre-Permian geology of the French

840 Massif Central. Comptes Rendus Géosciences, thematic issue «The Variscan Orogeny » 341: $841 \quad$ 202-213 doi :10.1016/j.crte.2008.12. 001 
843 Faure M, Cocherie A, Bé-Mézème E, Charles N, Rossi P (2010) Middle Carboniferous crustal 844 melting in the Variscan Belt: New insights from $\mathrm{U}-\mathrm{Th}-\mathrm{Pb}_{\mathrm{tot}}$. monazite and $\mathrm{U}-\mathrm{Pb}$ zircon ages 845 of the Montagne Noire Axial Zone (southern French Massif Central). Gondwana Research 846 633-673. doi 10.1016/j.gr.2010.02. 005.

847

848 Feybesse JL, Teygey M (1987) Evolution tectonométamorphique dévonienne de la série de la 849 Sioule. Géologie de la France 2 : 33-41

850

851 Franz G, Andrehs G, Rhede D (1996) Crystal chemistry of monazite and xenotime from 852 Saxothuringian-Moldanubian metapelites, NE Bavaria, Germany European J Mineralogy 8 : $853 \quad 1097-1118$

854

855 Grolier J (1971) Contribution à l'étude géologique des séries crystallophylliennes inverses du 856 massif Central français: la série de la Sioule (Puy de Dôme, Allier). Mem BRGM 64, 163pp. 857

858 Janots E, Negro F, Brunet F, Goffé B, Engi M, Bouybaouène ML (2006) Evolution of REE 859 mineralogy in HP-LT metapelites of the Sebtides complex, Rif, Morocco: Monazite stability 860 and geochronology. Lithos 87: 214-234

861

862 Jourdan F, Mark D, Verrati C (2014) Advances in ${ }^{40} \mathrm{Ar} /{ }^{39}$ Ar dating: from archaeology to 863 planetary sciences - introduction. Jourdan, F., Mark, D. F. \& Verati, C. (eds) 2014. Advances 864 in 40Ar/39Ar Dating: from Archaeology to Planetary Sciences. Geological Society, London, 865 Special Publications 378: 1-8 
867

868

869

870

871

872

873

874

875

876

877

878

879

880

881

882

883

884

885

886

887

888

889

890

Joly A, Chen Y, Faure M, Martelet G (2007) A multidisciplinary study of a syntectonic pluton close to a major lithospheric-scale fault: relationships between the Montmarault granitic massif and the Sillon Houiller Fault in the Variscan French Massif Central. Part I:

Geochronology, mineral fabrics and tectonic implications. J. Geophys. Res., 112, B10104, http://dx.doi.org/10.1029/2006JB004745

Kelly N.M, Harley S.L, Möller A, (2012) Complexity in the behavior and recrystallization of monazite during high-T metamorphism and fluid infiltration. Chemical Geology 322-323 : $192-208$

Kohn JM, Malloy MA (2004) Formation of monazite via prograde metamorphic reactions among common silicates: implications for age determinations. Geochimica Cosmochimica Acta 68: 101-113

Lardeaux JM, Ledru P, Daniel I, Duchène S (2001) The Variscan French Massif Central - a new addition to the ultra-high pressure metamorphic "club": exhumation processes and geodynamic consequences. Tectonophysics $323: 143-167$

Lardeaux JM, Schulmann K, Faure M, Janousek V, Lexa O, Skrzypek E, Edel J-B, Stipska P (2014) The Moldanubian Zone in French Massif Central, Vosges/Schwarzwald and Bohemian Massif revisited: Differences and similarities. In «The Variscan Orogeny: Extent, Timescale and the Formation of the European Crust ». Schulmann K, Martínez Catalán J R, Lardeaux J M, Janousek V \& Oggiano G (eds). Geological Society, London, Special Publications 405: http://dx.doi.org/10.1144/SP405.14 
892 Ledru P, Lardeaux JM, Santallier D, Autran A, Quenardel JM, Floc'h JP, Lerouge G, Maillet

893 N, Marchand J, Ploquin A (1989) Où sont les nappes dans le Massif central français ? Bull.

894 Soc. Géol. France 8 : 605-618

895

896 Leloix C, Faure M, Feybesse JL, (1999) Hercynian polyphase tectonics in north-east French

897 Massif Central : the closure of the Brévenne Devonian-Dinantian rift. Int. J. Earth. Sci. 88:

$898 \quad 409-421$

899

900 Li XH, Liu Y, Li QL, Guo CH (2009) Precise determination of Phanerozoic zircon Pb/Pb age

901 by multicollector SIMS without external standardization. Geochemistry Geophysics

902 Geosystems 10 : Q04010, http://dx.doi.org/10.1029/2009GC002400

903

904 Linthout $\mathrm{K}$ (2007) Tripartite division of the system $2 \mathrm{REEPO}_{4}-\mathrm{CaTh}(\mathrm{PO} 4)_{2}-2 \mathrm{ThSiO}_{4}$,

905 Discreditation of Brabantite, and recognition of Cheraliteas the name for members dominated

906 by $\mathrm{CaTh}(\mathrm{PO} 4)_{2}$. The Canadian Mineralogist $45: 503-508$

907

908 Ludwig KR (2001) ISOPLOT/EX, version 2.49. A geochronological toolkit for Microsoft

909 Excel. Berkeley Geochronology Center, Berkeley, Special Publications, 4

910

911 Martins L, Farias Vlach S.R, Janasi VdA, (2009) Reaction microtextures of monazite:

912 Correlation between chemical and age domains in the Nazaré Paulista migmatite, SE Brazil.

913 Chemical Geology $261: 271-285$

914

915 
916 Matte P (1986) Tectonic and plate tectonic model for the Variscan belt of Europe.

917 Tectonophysics 126: 329-374

918

919 Matte P. (2001) The Variscan collage and orogeny (480-290 Ma) and the tectonic definition

920 of the Armorica microplate. Terra Nova 13: 122-128

921

922 Mc Farlane CRM, Frost BR (2009) Constraints on the early metamorphic evolution of

923 Broken Hill Australia, from in situ U-Pb dating and REE geochemistry of monazite. J

924 Metamorphic Geology 27: 3-17

925

926 Melleton J, Faure M, Cocherie A, (2009) Monazite U-Th/Pb chemical dating of the Early

927 Carboniferous syn-kinematic MP/MT metamorphism in the Variscan French Massif Central.

928 Bull. Soc. Géol. France 180: 283-292.

929

930 Melleton J, Gloaguen E, Frei D, Lima A (2011) U-Pb dating of columbite-tantalite from

931 Variscan rare-elements granites and pegmatites. Goldschmidt Conference Abstracts Min.

932 Mag. 75: 1432.

933

934 Mercier L, Lardeaux JM, Davy P (1991) On the tectonic significance of the retromorphic P-T

935 paths of the French Massif Central eclogites. Tectonics $10: 131-140$

936

937 Montel J.M, Foret S, Veschambre M, Nicollet C, Provost A (1996) Electron microprobe

938 dating of monazite. Chem Geol $131: 37-53$

939 
940 Murphy B, Cousens B, Braid L, Strachan R, Dostal J, Keppie D, Nance D (2011) Highly

941 depleted oceanic lithosphere in the Rheic Ocean: Implications for Paleozoic plate

942 reconstructions. Lithos, 123: 165-175

943

944 Nagy G, Draganits E, Demeny A, Panto G, Arkai P (2002) Genesis and transformations of

945 monazite, florencite and rhabdophane during medium grade metamorphism : examples from

946 the Sopron Hills, Eastern Alps. Chem Geol 191 : 25-46

947

948 Olliot E, Melleton J, Schneider J, Corsini M, Gardien V, Rolland Y (2015) Variscan crustal

949 thickening in the Maures-Tanneron massif (South Variscan belt, France): new in situ

950 monazite U-Th-Pb chemical dating of high-grade rocks. Bull. Soc. Géol France 186: 145-169.

951

952 Parrish $\mathrm{R}$ (1990) U-Pb dating of monazite and its application to geological problems.

953 Canadian Journal of Earth Sciences 27 : 1431-1450

954

955 Paquette JL, Monchoux P, Couturier JP (1995) Geochemical and isotopic study of a norite-

956 eclogite transition in the EuropeanVariscan belt: implication for $\mathrm{U}-\mathrm{Pb}$ zircon systematics in

957 metabasic rocks. Geochimica Cosmochimica Acta 59 : 1611-1622.

958

959 Pin C, Peucat J-J (1986) Ages des épisodes de métamorphisme paléozoïques dans le Massif

960 central et le Massif armoricain. Bull Soc Géol France 8: 461-469.

961

962 Pin C, Vielzeuf D (1988) Les granulites de haute pression d'Europe moyenne témoins d'une

963 subduction éo-hercynienne. Implication sur l'origine des groupes leptyno-amphiboliques. Bull

964 Soc Géol France 4: 13-20

965 
966 Pin C (1990) Variscan oceans: ages, origins and geodynamic implications inferred from

967 geochemical and radiometric data. Tectonophysics $177: 215-227$

968

969 Pin C (1991) Sr-Nd isotopic study of igneous and metasedimentary enclaves in some

970 Hercynian granitoids from the Massif Central, France In : Didier J, Barbarin B (eds)

971 Developments in Petrology 13 Enclaves and granite petrology Elsevier Amsterdam 333-343

972

973 Pommier A, Cocherie A, Legendre O (2002) EPMA Dating User's manual: age calculation

974 from electron probe microanalyser measurements of $\mathrm{U}-\mathrm{Th}-\mathrm{Pb}$. Bureau de Recherches

975 Géologiques et Minières (BRGM), 9.

976

977 Rasmussen B, Fletcher IR, Mc Naughton NJ (2001) Dating low-grade metamorphic events by

978 SHRIMP U-Pb analysis of monazite in shales. Geology 29 : 963-966

979

980 Ravier J, Chenevoy M (1979) Présence de formations granulitiques jalonnant un linéament

981 crustal dans la série crystallophyllienne de la Sioule (Massif central français). Comptes

982 Rendus Acad Sci II 288 : 1703-1706

983

984 Richard J (1938) Etude de la série cristallophyllienne renversée de la Sioule. Revue Sci.

985 Naturelles de la Haute Auvergne 4, 1: 37pp

986

987 Roig JY, Faure M (2000) La tectonique cisaillante polyphasée du Sud-Limousin. Bull. Soc.

988 Géol. France 171: 295-307

989 
990 Santallier N (1981) Les roches basiques de la série métamorphique du Bas-Limousin, Massif

991 Central (France), Thèse, Univ. Orléans, France, 350 pp

992

993 Schulz B, Triboulet C, Audren C, Feybesse JL (2001) P-T paths from metapelite garnet

994 zonations, and crustal stacking in the Variscan inverted metamorphic sequence of La Sioule,

995 French Massif Central. Z dt Geol Ges $152: 1-25$

996

997 Schulz B (2009) EMP-monazite age controls on P-T paths of garnet metapelites in the

998 Variscan inverted metamorphic sequence of La Sioule, French Massif Central. Bull. Soc.

999 Géol. Fr. $180: 271-282$

1000

1001 Smith HA, Barreiro B (1990) Monazite U-Pb dating of staurolite grade metamorphism in 1002 pelitic schists. Contribution Mineral Petrol 105 : 602-615

1003

1004 Stacey JS, Kramers JD (1975) Approximation of terrestrial lead isotope evolution by a two-

1005 stage model. Earth and Planetary Science Letters 26 : 207-221

1006

1007 Suzuki K, Adachi M (1991) Precambrian provenance and Silurian metamorphism of the

1008 Tsubonosawa paragneiss in the South Kitakami terrane, Northeast Japan, revealed by the

1009 chemical Th-U-total $\mathrm{Pb}$ isochron ages of monazite, zircon and xenotime. Geochem J 25 : 357-

1010376

1011

1012 Talbot JY, Faure M, Chen Y, Martelet G, (2005) Pull apart emplacement of the Margeride

1013 granitic complex (French Massif Central). Implications for the Late evolution of the Variscan

1014 orogen. J. Struct. Geol. 27: 1610-1629 
1015

1016 Wendt I, Carl C (1991) The statistical distribution of the mean squared weighted deviation.

1017 Chem Geol $86: 275-285$

1018

1019 Wiedenbeck M, Allen P, 1995. Three natural zircon standards for U-Th-Pb, Lu-Hf, trace 1020 element and REE analysis. Geostandards Newsletter $19: 1-23$

1021

1022

1023

1024 Figure Captions

1025 Fig. 1. A: Location of the French Massif Central in the European Variscan framework. B:

1026 Structural map of the Massif Central (modified from Ledru et al., 1989, and Faure et al., 1027 2009). $D_{1}, D_{2}, D_{3}$ refer to the stretching lineation and kinematics referred to the Early

1028 Devonian, Early Carboniferous, and Middle Carboniferous tectono-metamorphic events,

1029 respectively. SGA: $\mathrm{S}^{\mathrm{t}}$-Gervais d'Auvergne pluton

1030

1031 Fig. 2. Structural map, and NW-SE cross-section of the Sioule series with sampling sites and 1032 microstructural data, after Grolier (1971), Feybesse and Teygey (1987), and Faure et al. 1033 (1993).

1034

1035 Fig. 3. Examples of representative macroscopic field structures of the Para-autochthonous (a), 1036 Lower Gneiss (b) and Upper Gneiss (c, d) Units. a1: outcrop of biotite-staurolite micaschist 1037 of sample SO3, with top-to-the-SE sigmoidal quart veins, a2: close-up of the mineral lineation 1038 marked by elongated biotite and staurolite porphyroblasts. This NW-SE lineation results of 1039 the superposition of $\mathrm{D}_{2}$ and $\mathrm{D}_{4}$ events. b) D1 NE-SW striking isoclinal folds at Chouvigny. c) 
1040 Biotite-sillimanite paragneiss with S1 flat-lying foliation and L1 mineral lineation, close to

1041 sample SO7. d) hand sample of garnet-kyanite granulitic paragneiss at Saugères (sample SO

1042 15). Note the biotite rim around garnet developed during the retrogression of the granulite

1043 facies metamorphic assemblage into ampohibolite facies ones.

1044

1045 Fig. 4. Polarized light micrographs of analyzed samples showing the textural relationships of 1046 the dated monazite grains with other minerals (see location in Fig. 2). a: PAU micaschist 1047 sample SO3 from the Para-autochthonous Unit showing $\mathrm{D}_{2}$ staurolite mantled by a sericite

1048 rim and deformed during the $\mathrm{D}_{4}$ event. b: biotite-garnet-sillimanite gneiss (sample SO7) from 1049 the Upper Gneiss Unit with monazite included in biotite. c: biotite-sillimanite migmatite 1050 (sample SO11) foliated and lineated during the $\mathrm{D}_{2}$ event, the dated monazite is included in 1051 biotite. d: kyanite-garnet granulitic paragneiss (sample SO15) with garnet surrounded by a 1052 biotite rim developed during the $\mathrm{D}_{2}$ event.

1053

1054 Fig. 5. a: plot of the analyzed monazites in the $2 \mathrm{REEPO}_{4}-\mathrm{CaTh}\left(\mathrm{PO}_{4}\right)_{2}-2 \mathrm{ThSIO}_{4}$ system 1055 (Linthout, 2007) showing that the grains are close to the Ce-monazite pole. b: plot of the 1056 analyzed monazite in the $\mathrm{Th}+\mathrm{U}+\mathrm{Si}+\mathrm{Pb}$ vs $\mathrm{REE}+\mathrm{P}$ diagram (Franz et al., 1996). c: weighted 1057 average age of the core and rim of monazite contained in kyanite-garnet paragneiss of 1058 Saugères (sample SO15). d: X-ray compositional map for Th, Ca, U of the analyzed monazite 1059 grain in the granulitic paragneiss sample SO15, showing the chemical zoning with a Th, Ca, 1060 and $U$ enriched rim. White and black squares represent EPMA analyse points for core and 1061 rim, respectively.

1062

1063 Fig. 6. $\mathrm{Th} / \mathrm{Pb}$ vs U/Pb plots with SEM BSE pictures of dated monazites, sample location 1064 shown on Fig. 2, and GPS in Table 1. a, b, c, b: Upper Gneiss Unit. a) core of monazite grain 
1065 from SO 15 granulite (Saugères); b) rim of monazite grain from SO15 granulite (Saugères); c)

1066 biotite-sillimanite migmatitic gneiss SO11 from Pont de Menat; d) biotite-sillimanite

1067 migmatitic paragneiss SO7 from Moulin de Bouchet; e) biotite-staurolite micaschist SO3

1068 from the Para-autochthonous Unit; f) two-mica paragneiss SO17 from the Lower Gneiss Unit.

1069

1070 Fig. 7. Cathodoluminescence (CL) images for representative zircons sample SO 15. The white

1071 ellipses in the CL images represent the spots of SIMS U-Pb analysis. SIMS spots are $30 \mu \mathrm{m}$ in 1072 length for scale.

1073

1074 Fig. 8. Probability histogram of U-Pb age for 51 concordant analyses showing the two groups 1075 of zircon ages. Group 1 zircons have a main peak at $342 \mathrm{Ma}$ and a secondary one at 327 Ma.

1076

1077 Fig. 9. Zircon U-Pb Concordia age of granulitic paragneiss sample S015.

1078

1079 Fig. 10. Synthetic map summarizing the available radiometric ages obtained through different

1080 methods, whole rock $\mathrm{Rb} / \mathrm{Sr}$, biotite and muscovite ${ }^{40} \mathrm{Ar} /{ }^{39} \mathrm{Ar}$, monazite U-Th- $\mathrm{Pb}$, and zircon

1081 U-Pb SIMS for the Sioule series.

1082

1083 Fig. 11. Synoptic chart of the radiometric ages from the Sioule series presented in this paper,

1084 compared with the ages of the $\mathrm{D}_{1}, \mathrm{D}_{2}, \mathrm{D}_{3}$ tectono-thermal events for the French Massif

1085 central, and the Guéret and $\mathrm{S}^{\mathrm{t}}$-Gervais biotite granites, and Pouzol-Servant microgranite.

1086 (1): Average biotite, muscovite, and hornblende ${ }^{40} \mathrm{Ar} /{ }^{39} \mathrm{Ar}$ ages from Faure et al. (2002); (2):

1087 zircon U-Pb age of the Pouzol-Servant microganite (Pin 1991); (3): zircon U-Pb SHRIMP and

1088 monazite U-Th-Pb chemical ages of the Guéret-St-Gervais plutons (Cartannaz et al. 2007). 
1090 Fig. 12. P-T-t paths for the Upper Gneiss Unit (UGU), Lower Gneiss Unit (LGU), and Para-

1091 Autochthonous Unit (PAU) modified from Mercier et al. 1991, Lardeaux et al., 2001; Schulz

1092 et al., 2001; Bellot and Roig 2007; Faure et al. 2007; Schulz 2009) emphasizing the

1093 polycyclic evolution. During the eo-Variscan cycle, the UGU experienced the $\mathrm{D}_{0}$ high to

1094 ultra-high pressure metamorphism, and Devonian migmatization during its $\mathrm{D}_{1}$ exhumation.

1095 The LGU underwent burial under lower pressure conditions than the UGU, then Devonian

1096 exhumation and migmatization during $\mathrm{D}_{1}$. During the Late Devonian-Early Carboniferous $\mathrm{D}_{2}$

1097 event, the PAU followed its first burial and exhumation cycle, whereas the LGU and UGU

1098 experienced a second metamorphic cycle before its Late Visean exhumation.

1099

1100 Table 1. Dated sample locations and analytical data

1101

1102 Table 2. Electron microprobe analyses of dated monazites

1103

1104 Table 3. Zircon U-Pb zircon analyses of granulitic paragneiss sample SO15 


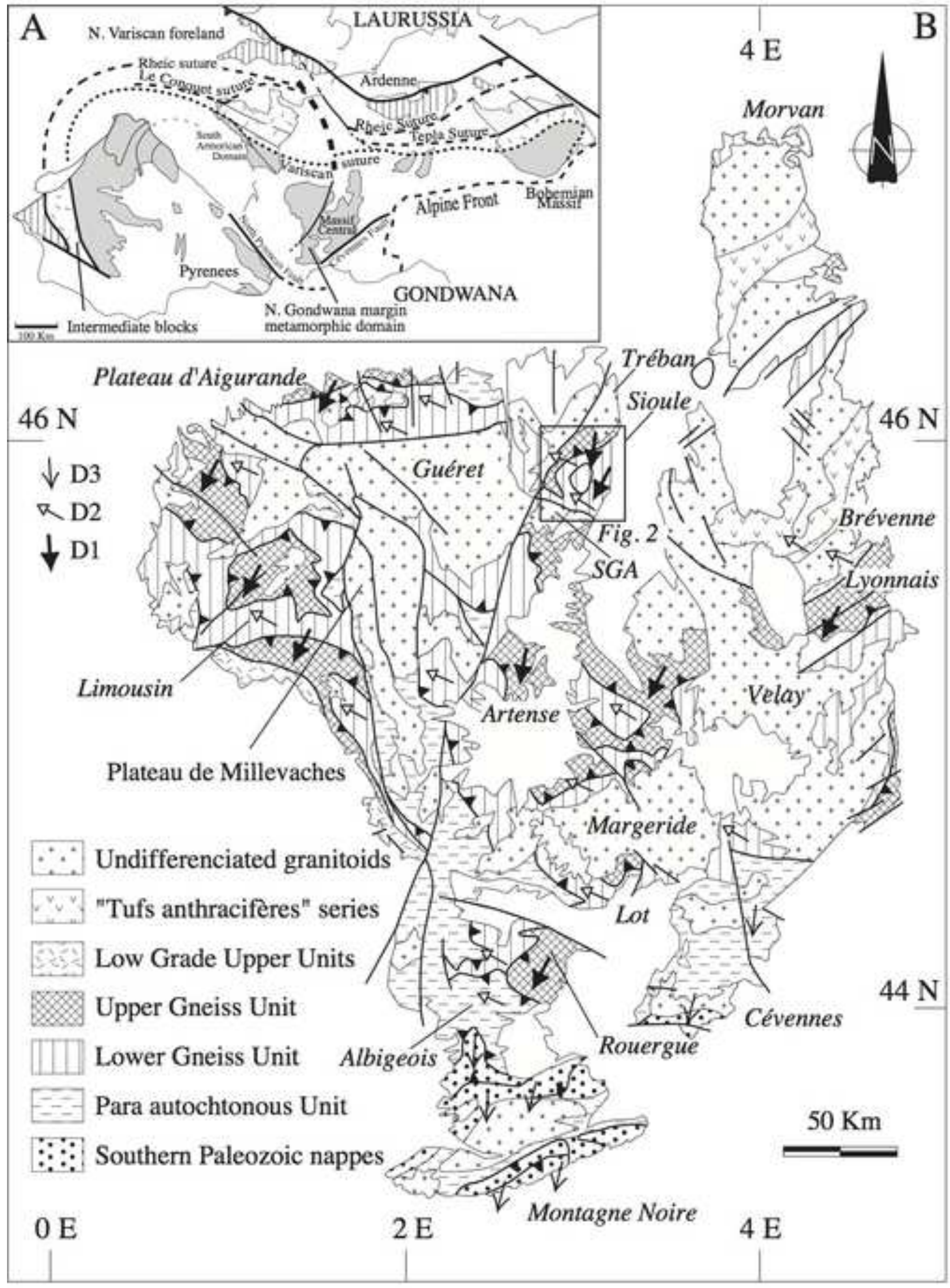




\section{Figure 2}

Click here to download high resolution image

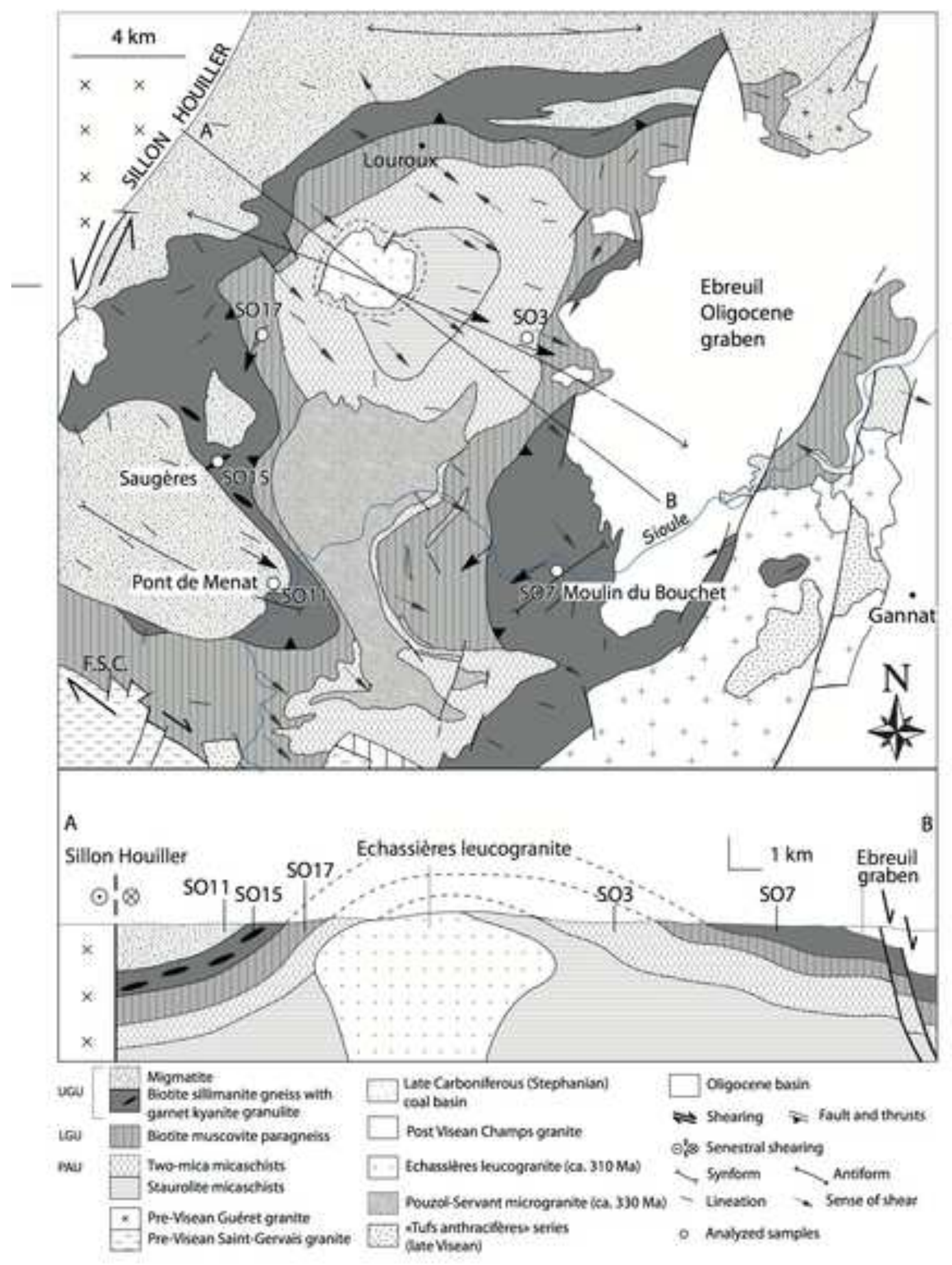


Click here to download high resolution image
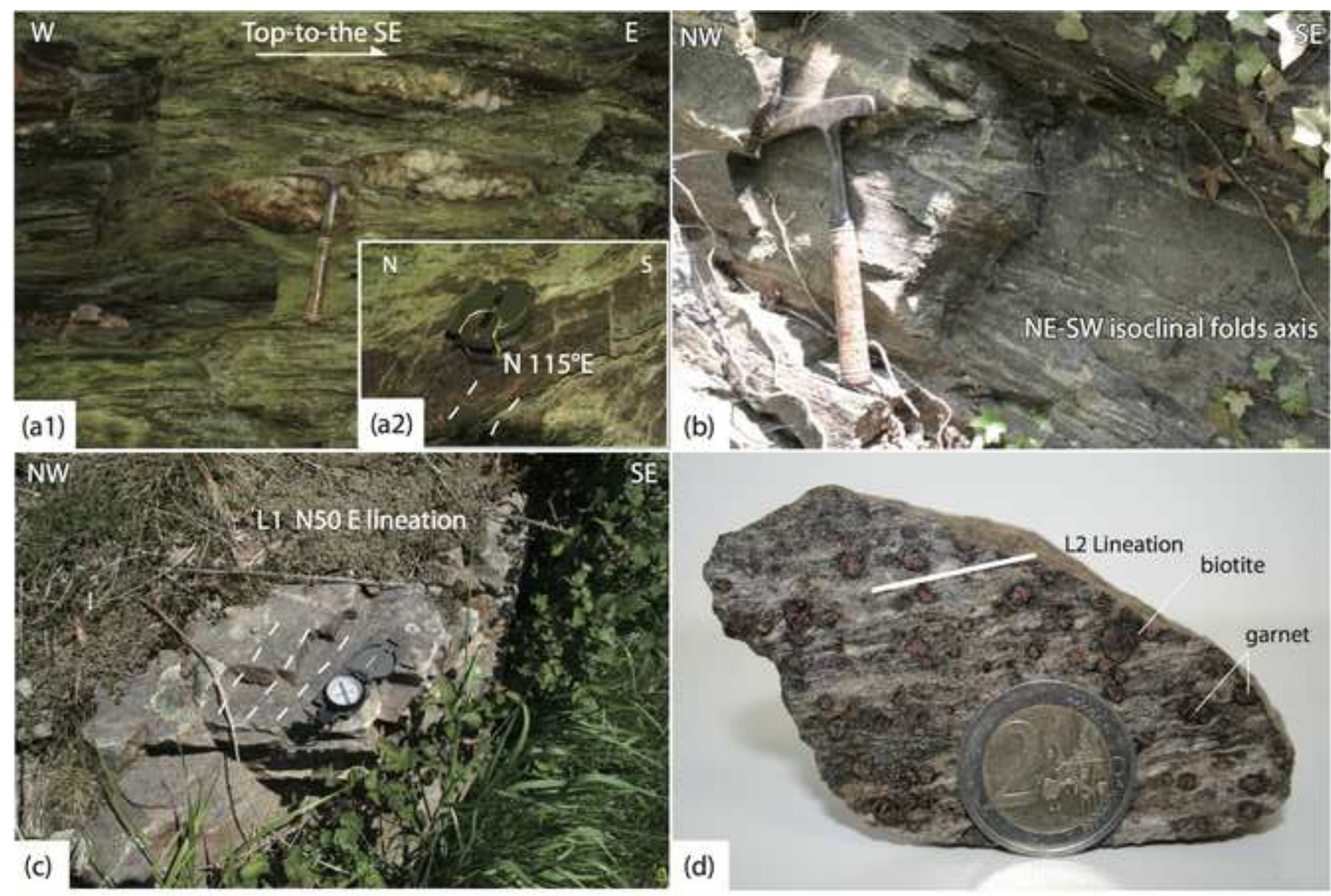


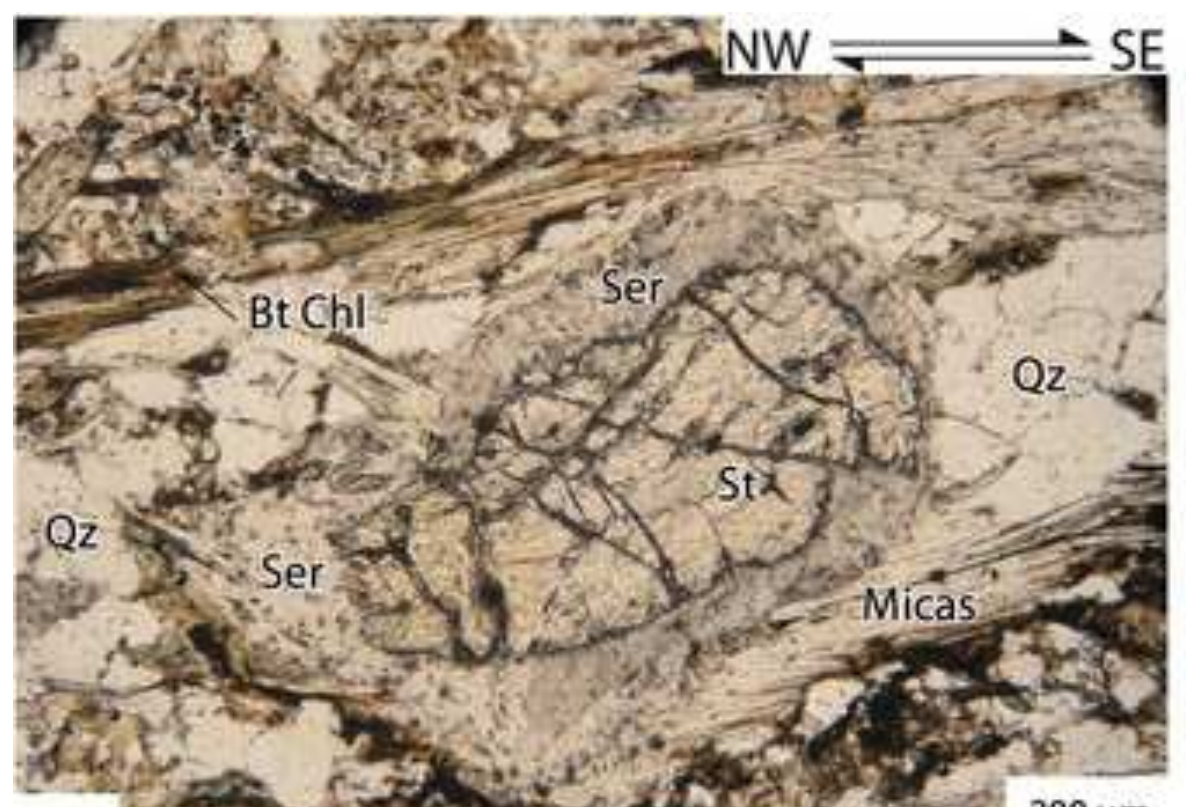

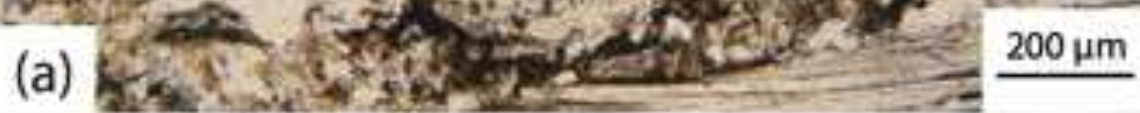

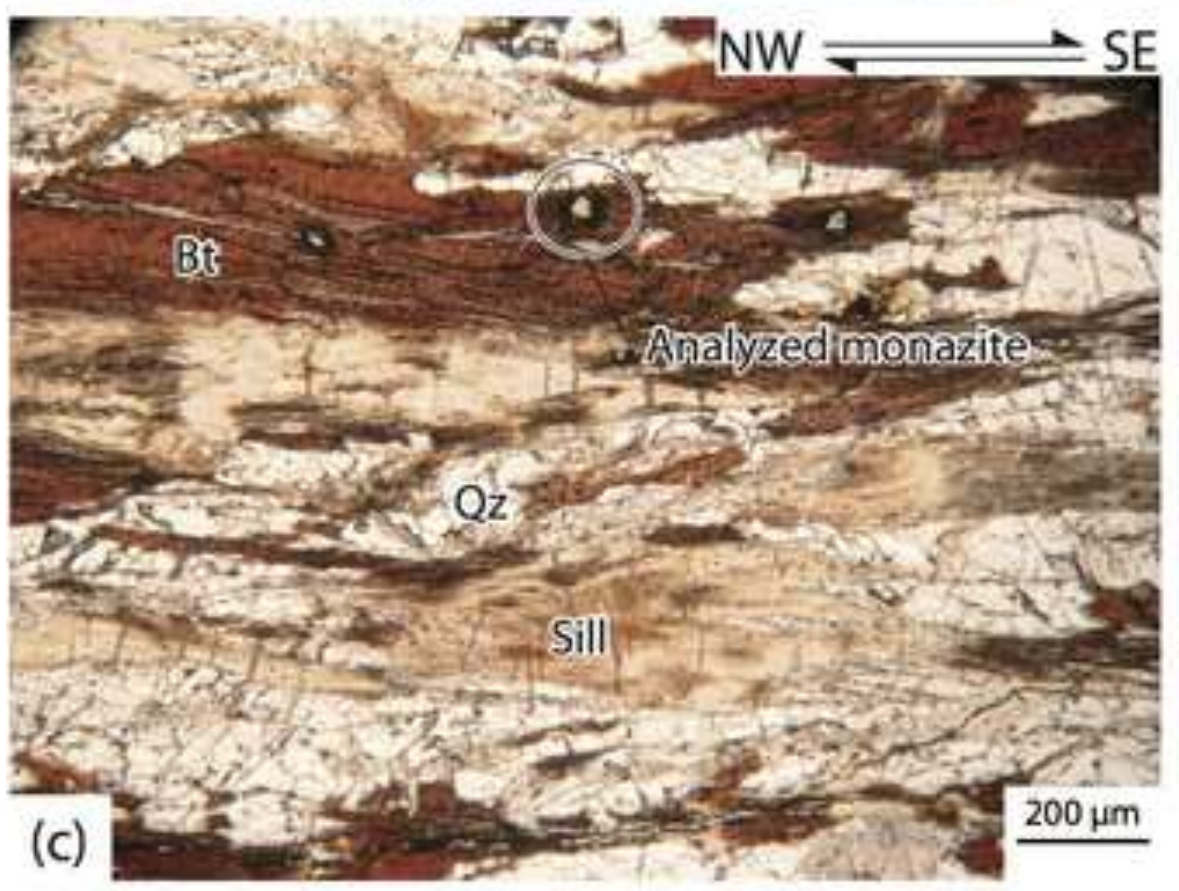

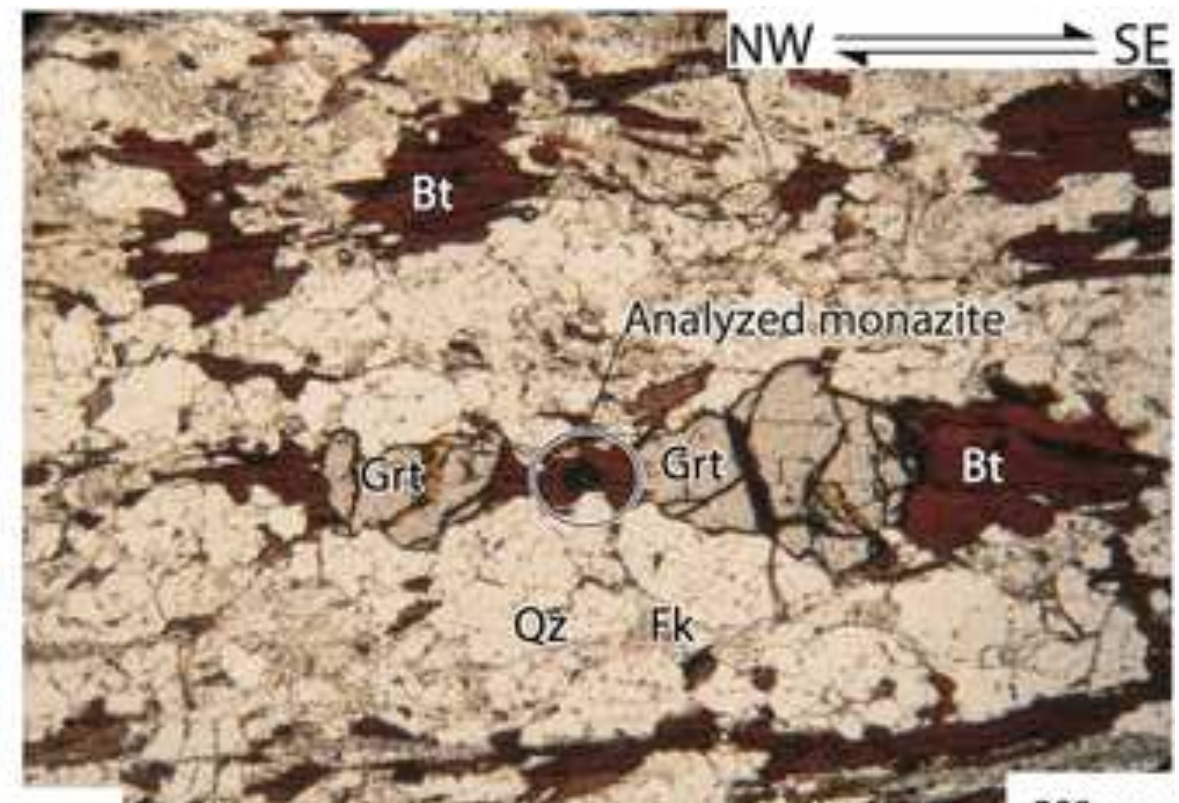

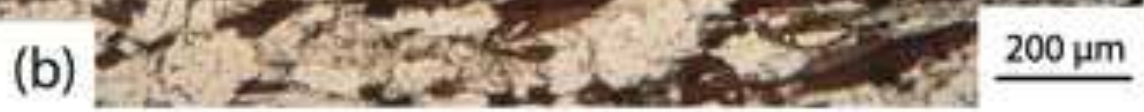

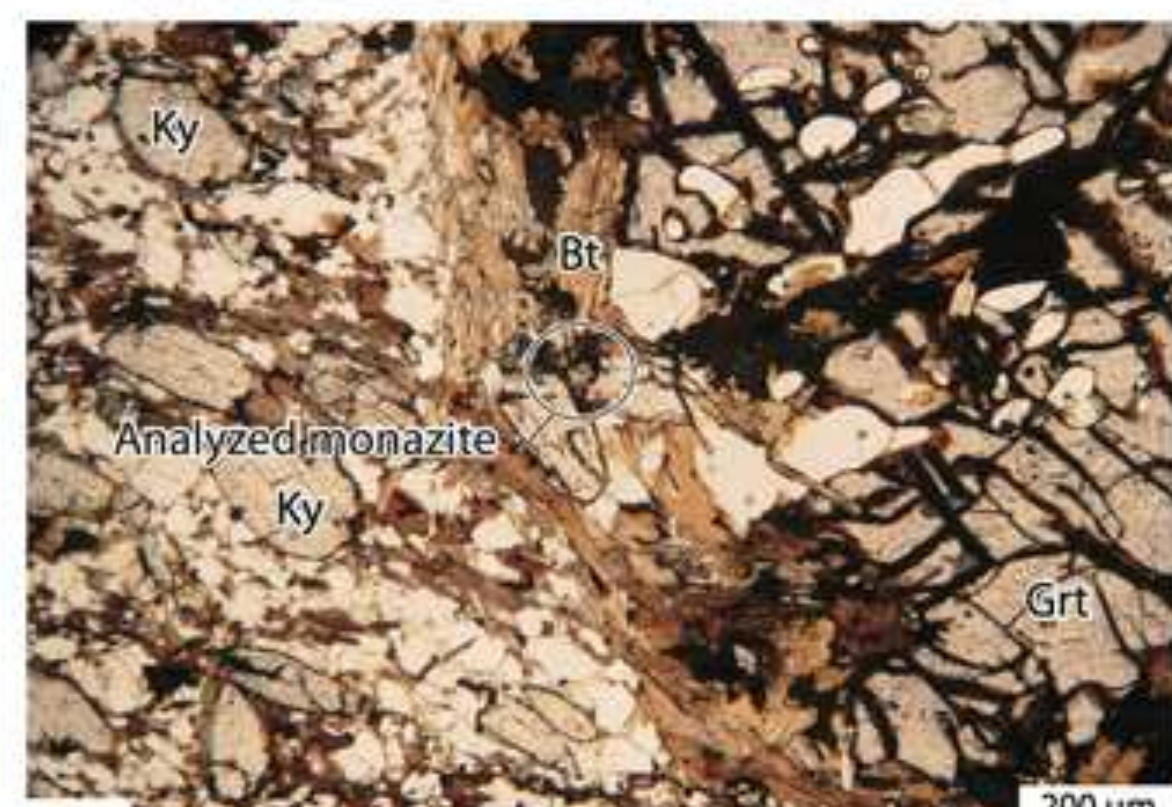

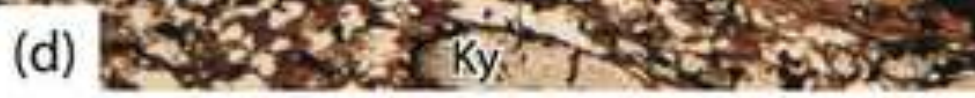

$200 \mu \mathrm{m}$ 


\section{Figure 5}

Click here to download high resolution image
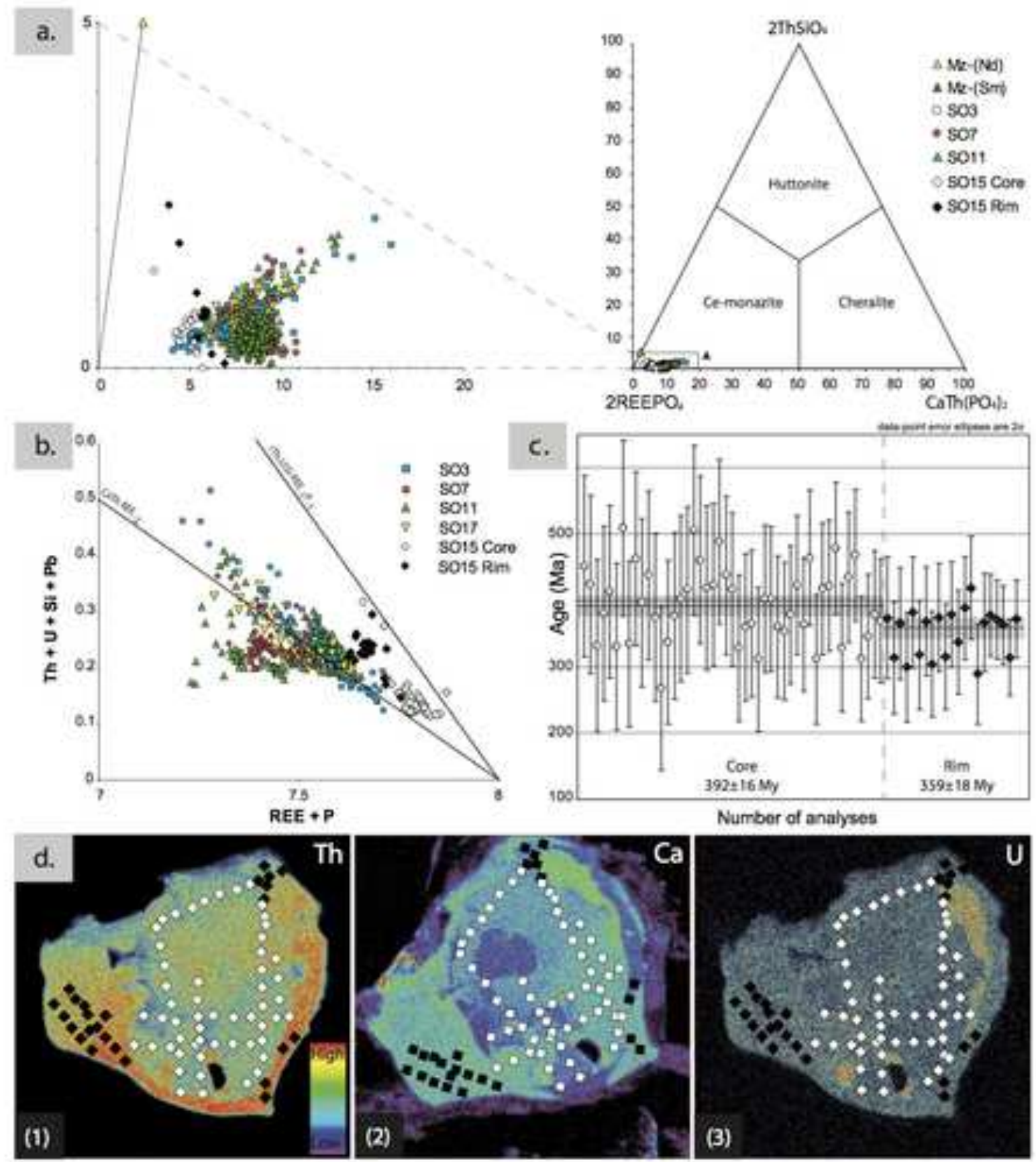

Fig. 5 
Click here to download high resolution image

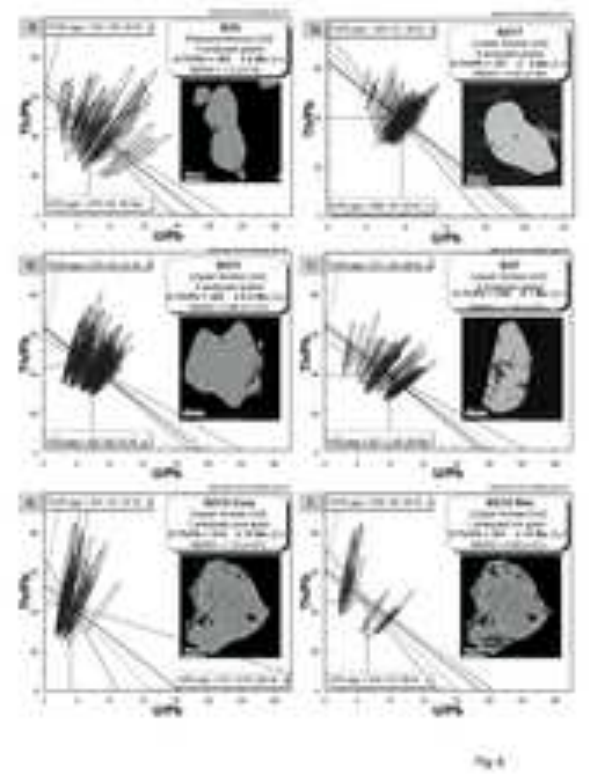


@28 $327 \mathrm{Ma}$

@13 $342 \mathrm{Ma}$

\section{@25 $349 \mathrm{Ma}$}
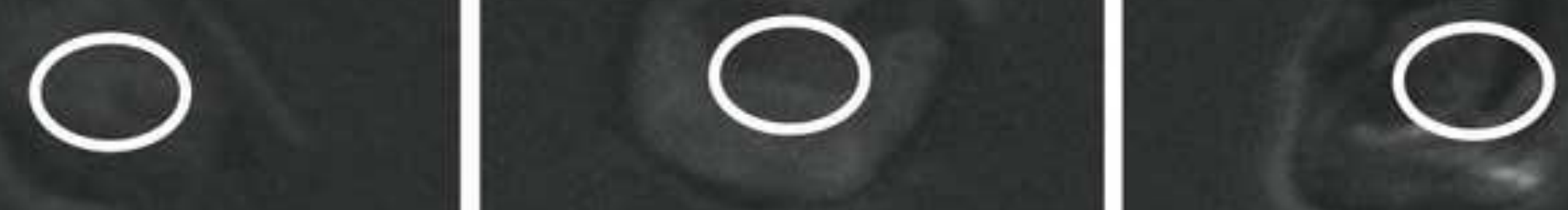

@31 $389 \mathrm{Ma}$

@07 $457 \mathrm{Ma}$

@06 $1994 \mathrm{Ma}$
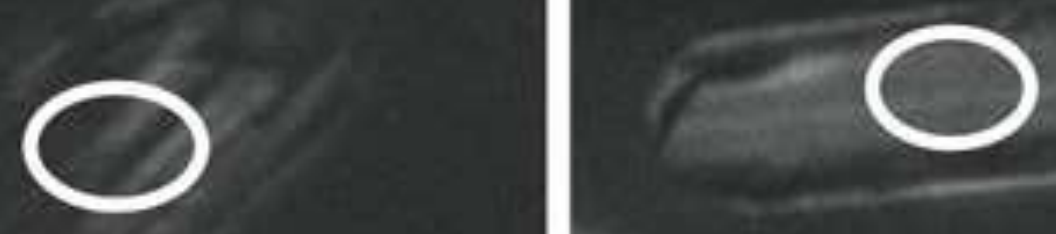

Fig. 2 


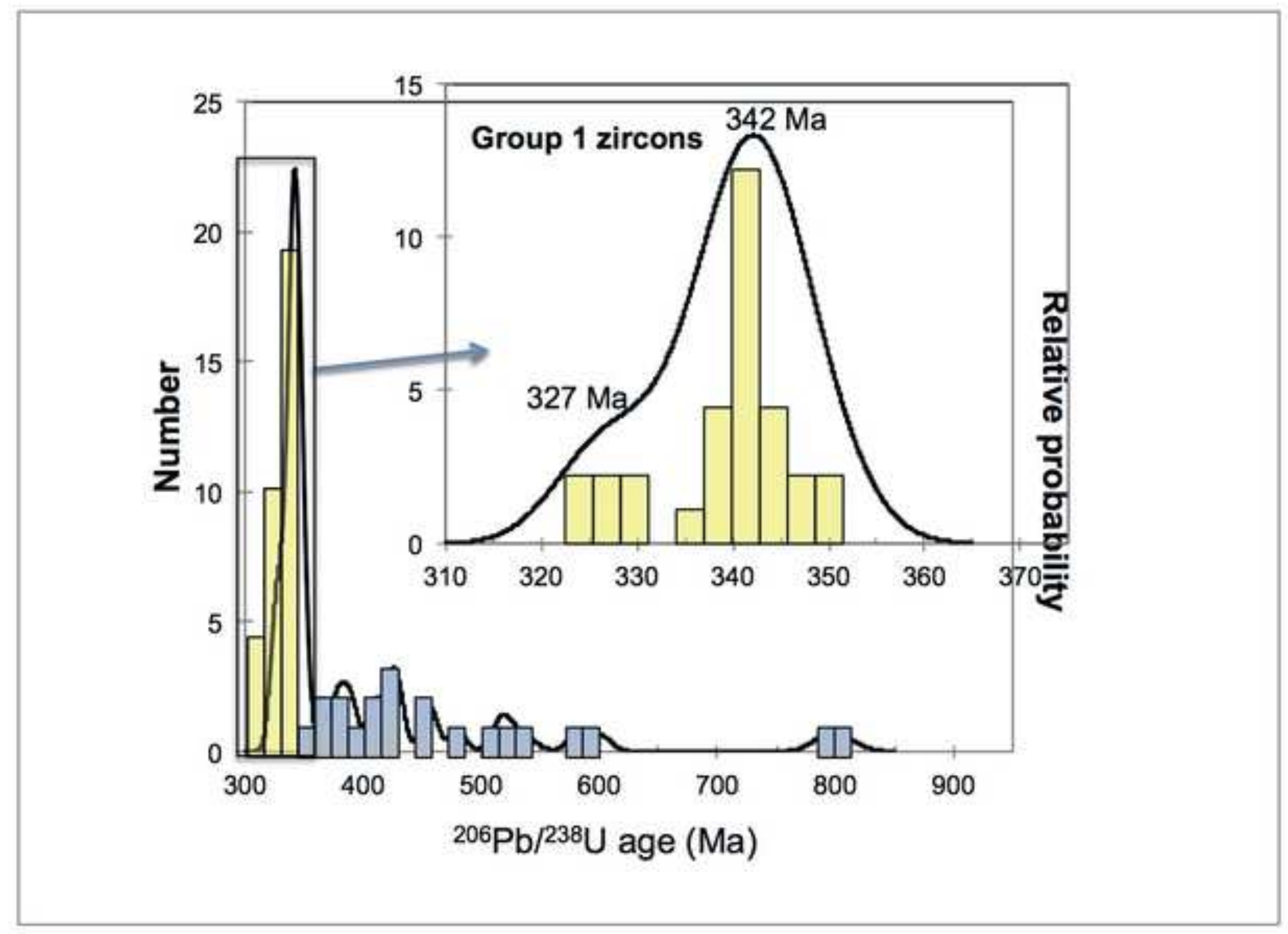




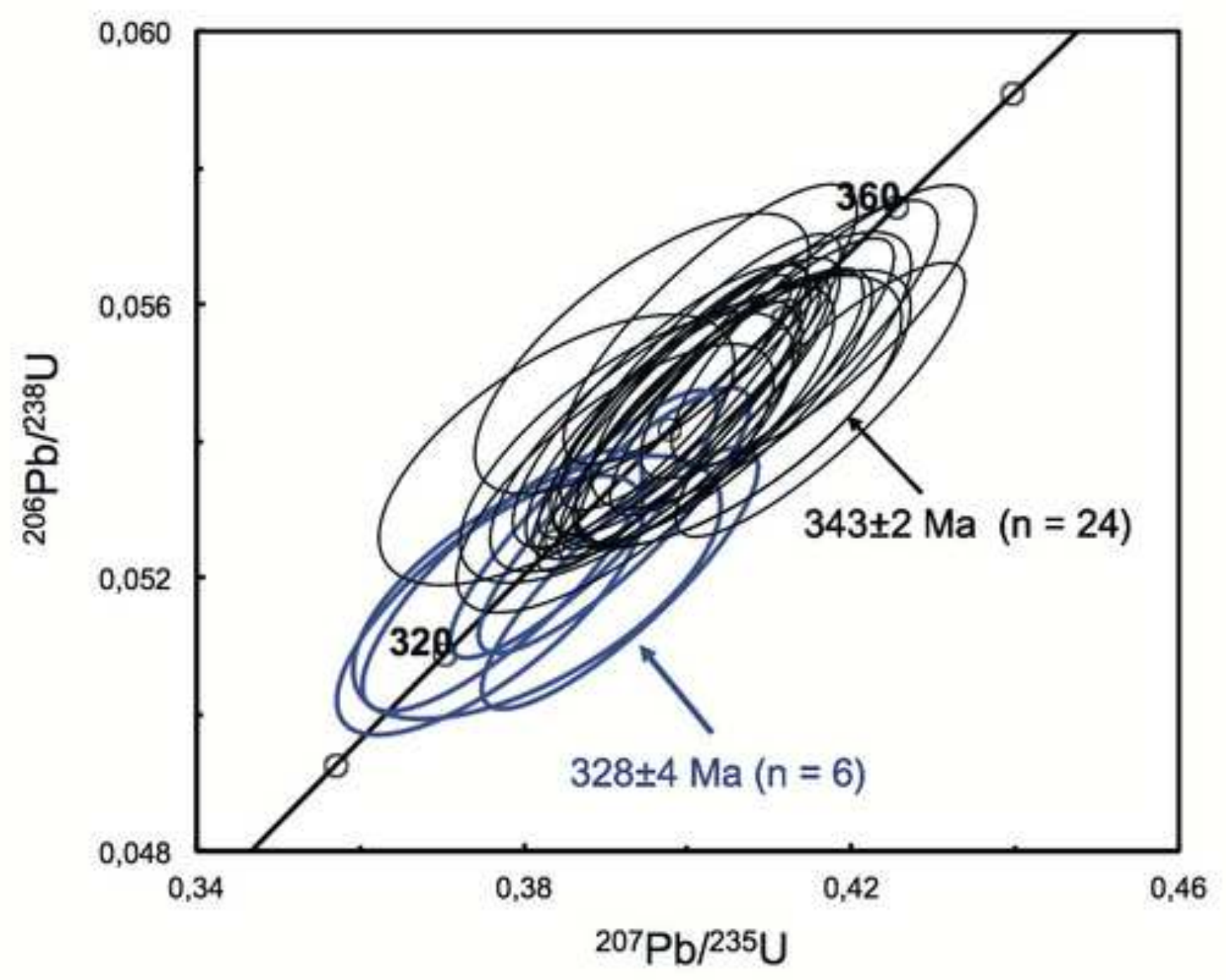




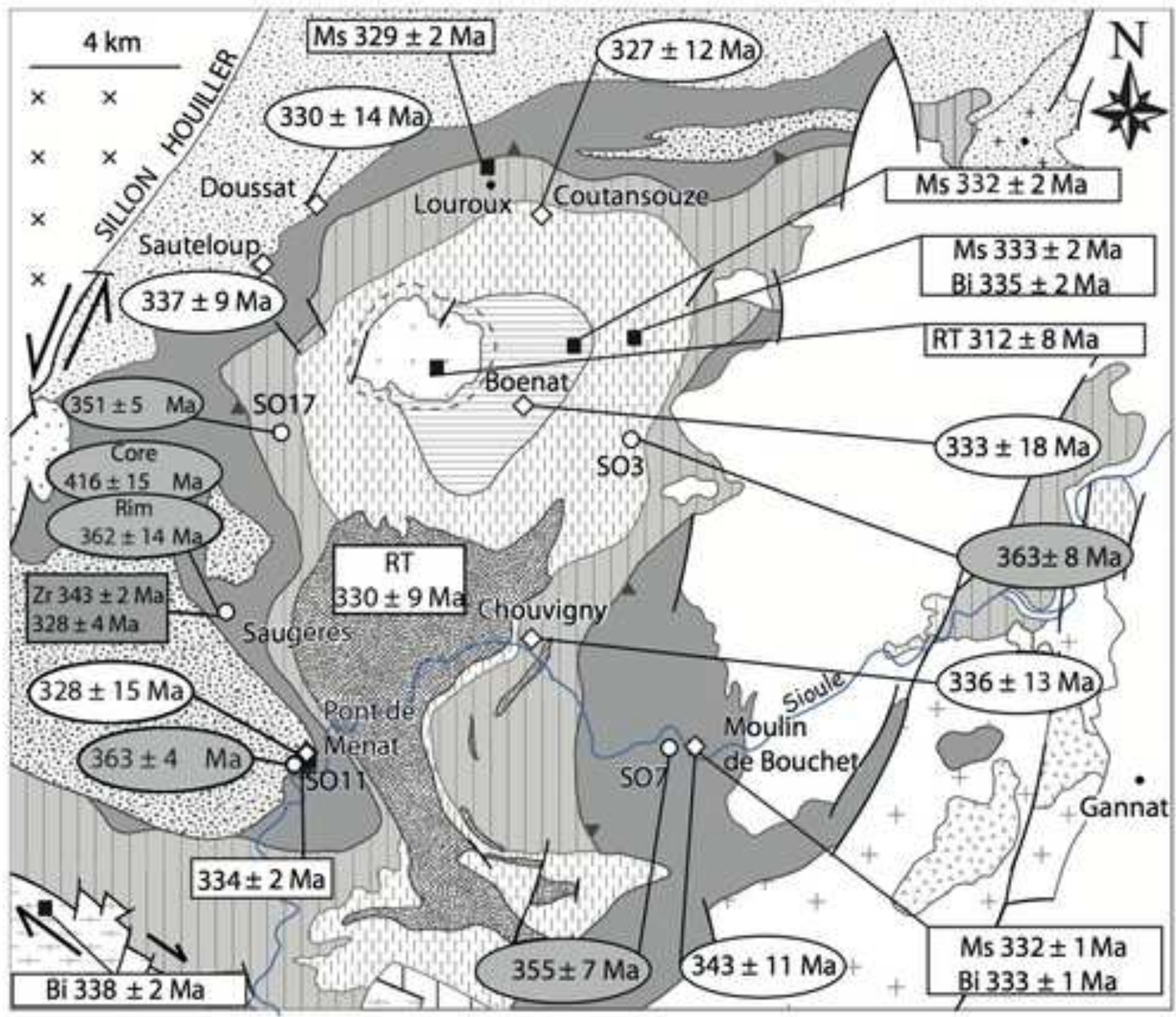

Bi $337.6 \pm 2 \mathrm{Ma}$ Biotite and muscovite $\mathrm{Ar} / \mathrm{Ar}$ age (Faure et al., 2002)

RT $312 \pm 8 \mathrm{Ma}$

$2+343 \pm 2 \mathrm{Ma}$ $328 \pm 4 \mathrm{Ma}$
Whole rock $\mathrm{Rb} / \mathrm{Sr}$ age

(Duthou et Pin, 1987

Zircon U-Pb SIMS age

(this study)
Pin, 1991)
$343 \pm 11 \mathrm{Ma}$ Monazite U-Th-Pb chemical age

(Schulz et al., 2009)

$355 \pm 7$ Ma)

Monazite U-Th-Pb chemical age

(this study)

Fig. 10 
Figure 11

Click here to download high resolution image

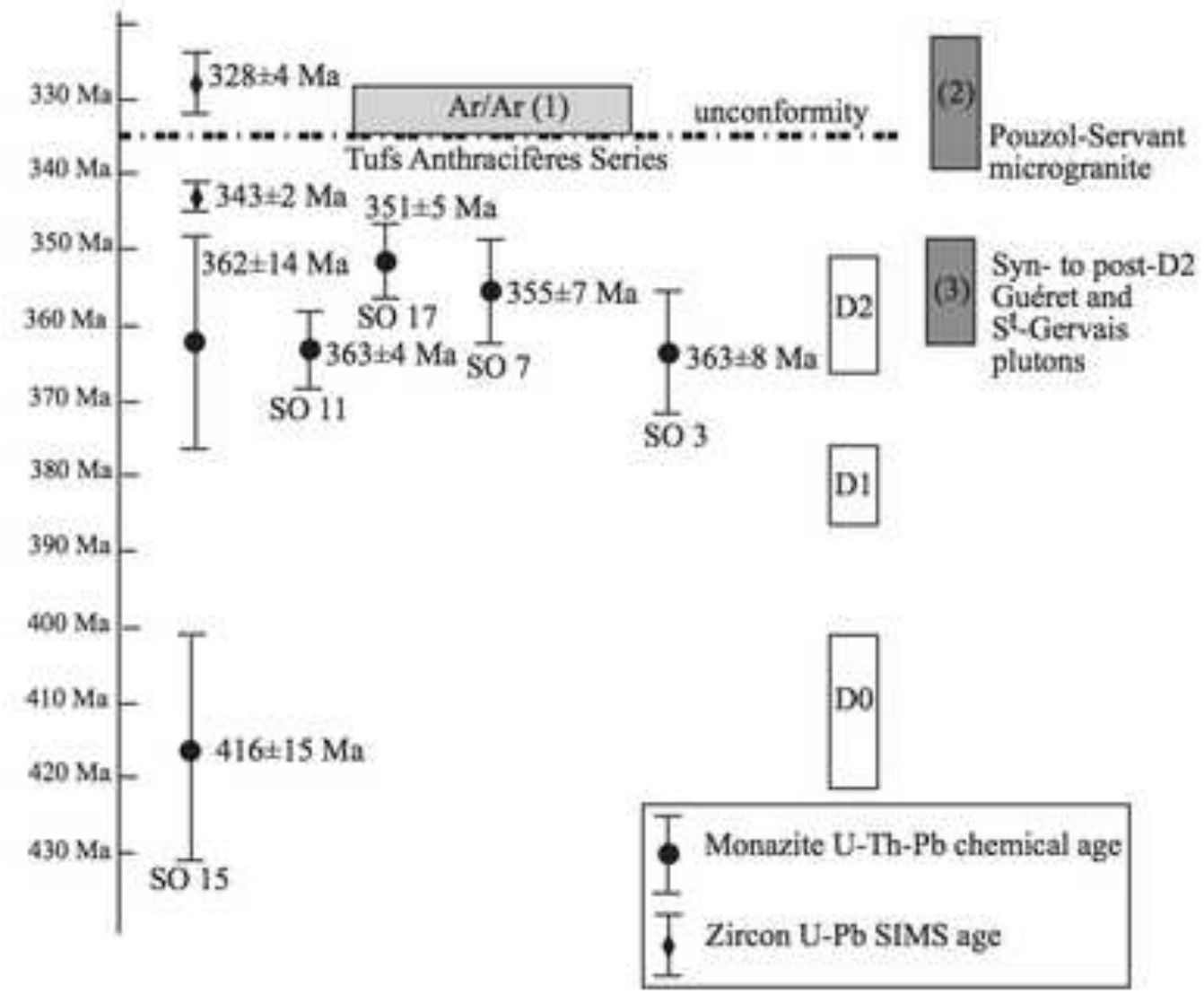

Fig. II 


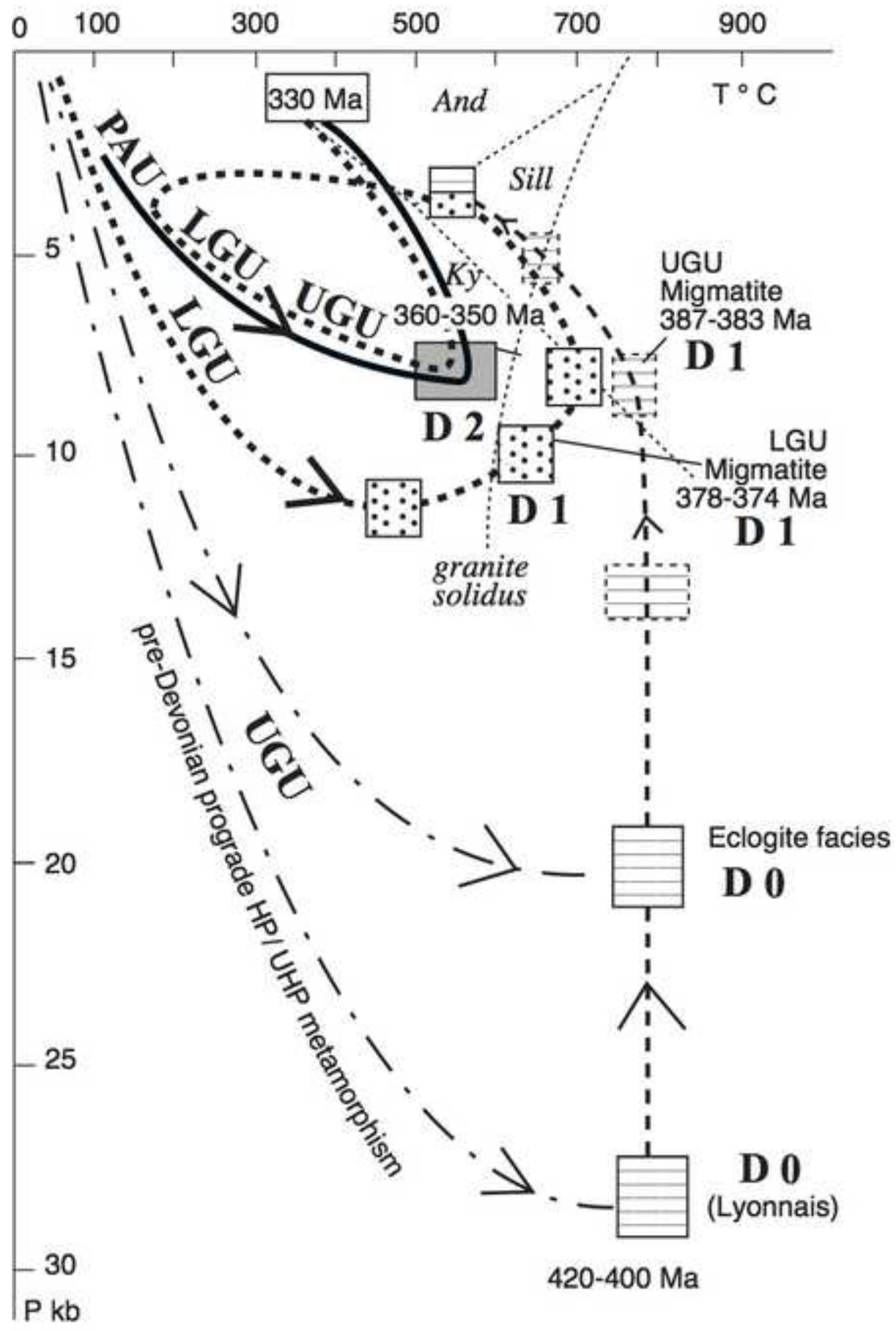

Fig. 12 
Table 1. Dated sample locations and analytical data

\begin{tabular}{|c|c|c|c|c|c|c|c|c|c|c|}
\hline Sample & LAT & LON & $\begin{array}{l}\text { Nbr of } \\
\text { grains }\end{array}$ & $\mathrm{Pb}$ (ppm) & U (ppm) & Th (ppm) & $\mathrm{U} / \mathrm{Pb}$ & $\mathrm{Th} / \mathrm{Pb}$ & $\begin{array}{c}\text { Isochron } \\
\text { age } \pm 2 \sigma\end{array}$ & $\bar{n}$ \\
\hline $\mathrm{SO} 3$ & $46^{\circ} 10^{\prime} 19.25^{\prime \prime}$ & $3^{\circ} 01^{\prime} 30.80^{\prime \prime}$ & 4 & $\begin{array}{c}839 \\
\pm \\
253\end{array}$ & $\begin{array}{c}4885 \\
\pm \\
1596\end{array}$ & $\begin{array}{c}37366 \\
\pm \\
14335\end{array}$ & $\begin{array}{c}6.2 \\
\pm \\
2.3\end{array}$ & $\begin{array}{c}44.2 \\
\pm \\
8\end{array}$ & $\begin{array}{c}363 \\
\pm \\
8\end{array}$ & 73 \\
\hline SO7 & $46^{\circ} 06^{\prime} 09.60^{\prime \prime}$ & $3^{\circ} 02^{\prime} 28.20^{\prime \prime}$ & 4 & $\begin{array}{c}1013 \\
\pm \\
147\end{array}$ & $\begin{array}{c}8039 \\
\pm \\
2514\end{array}$ & $\begin{array}{c}39089 \\
\pm \\
5186\end{array}$ & $\begin{array}{c}7.9 \\
\pm \\
2\end{array}$ & $\begin{array}{c}39.1 \\
\pm \\
6.3\end{array}$ & $\begin{array}{c}355 \\
\pm \\
7\end{array}$ & 73 \\
\hline SO11 & $46^{\circ} 06^{\prime} 01.19^{\prime \prime}$ & $2^{\circ} 55^{\prime} 15.60^{\prime \prime}$ & 4 & $\begin{array}{c}914 \\
\pm \\
138\end{array}$ & $\begin{array}{c}5365 \\
\pm \\
1296\end{array}$ & $\begin{array}{c}39639 \\
\pm \\
5835\end{array}$ & $\begin{array}{c}5.9 \\
\pm \\
1.2\end{array}$ & $\begin{array}{c}43.8 \\
\pm \\
5.4\end{array}$ & $\begin{array}{c}363 \\
\pm \\
4\end{array}$ & $\begin{array}{c}17 \\
4\end{array}$ \\
\hline $\begin{array}{l}\text { SO15 } \\
\text { Rim }\end{array}$ & $46^{\circ} 07^{\prime} 46.99^{\prime \prime}$ & $2^{\circ} 54^{\prime} 05.36^{\prime \prime}$ & 1 & $\begin{array}{c}586 \\
\pm \\
103\end{array}$ & $\begin{array}{c}1960 \\
\pm \\
614\end{array}$ & $\begin{array}{c}26843 \\
\pm \\
3470\end{array}$ & $\begin{array}{c}3.4 \\
\pm \\
1\end{array}$ & $\begin{array}{c}46.8 \\
\pm \\
7.9\end{array}$ & $\begin{array}{c}361 \\
\pm \\
14\end{array}$ & 47 \\
\hline $\begin{array}{l}\text { SO15 } \\
\text { Core }\end{array}$ & & & 1 & $\begin{array}{c}808 \\
\pm \\
160\end{array}$ & $\begin{array}{c}3922 \\
\pm \\
2648\end{array}$ & $\begin{array}{c}38519 \\
\pm \\
3886\end{array}$ & $\begin{array}{c}4.5 \\
\pm \\
2.2\end{array}$ & $\begin{array}{c}49.5 \\
\pm \\
11.1\end{array}$ & $\begin{array}{c}416 \\
\pm \\
15\end{array}$ & 21 \\
\hline S017 & $46^{\circ} 10^{\prime} 31.26^{\prime \prime}$ & $2^{\circ} 54^{\prime} 48.07^{\prime \prime}$ & 6 & $\begin{array}{c}1179 \\
\pm \\
235\end{array}$ & $\begin{array}{c}8347 \\
\pm \\
1141\end{array}$ & $\begin{array}{c}49787 \\
\pm \\
15110\end{array}$ & $\begin{array}{c}7.2 \\
\pm \\
1.2\end{array}$ & $\begin{array}{c}41.8 \\
\pm \\
4.8\end{array}$ & $\begin{array}{c}351 \\
\pm \\
5\end{array}$ & 38 \\
\hline
\end{tabular}


Table 2. Electron microprobe analyses of dated monazites

\begin{tabular}{|c|c|c|c|c|c|c|c|c|c|c|c|c|c|}
\hline Sample & $\mathrm{UO}_{2}$ & $\mathrm{PbO}$ & $\mathrm{Nd}_{2} \mathrm{O}_{3}$ & $\mathrm{CaO}$ & $\mathrm{P}_{2} \mathrm{O}_{5}$ & $\mathrm{ThO}_{2}$ & $\mathrm{Gd}_{2} \mathrm{O}_{3}$ & $\mathrm{Ce}_{2} \mathrm{O}_{3}$ & $\mathrm{SiO}_{2}$ & $\mathrm{Sm}_{2} \mathrm{O}_{3}$ & $\mathrm{La}_{2} \mathrm{O}_{3}$ & $\mathrm{Y}_{2} \mathrm{O}_{3}$ & $\mathrm{Pr}_{2} \mathrm{O}_{3}$ \\
\hline \multirow{3}{*}{$\mathrm{SO} 3$} & 0.55 & 0.10 & 12.27 & 0.88 & 29.27 & 4.25 & 1.34 & 29.27 & 0.67 & 2.21 & 14.08 & 0.99 & 3.51 \\
\hline & \pm & \pm & \pm & \pm & \pm & \pm & \pm & \pm & \pm & \pm & \pm & \pm & \pm \\
\hline & 0.18 & 0.03 & 0.54 & 0.27 & 0.5 & 1.63 & 0.28 & 0.94 & 0.99 & 0.16 & 0.78 & 0.26 & 0.15 \\
\hline \multirow{3}{*}{ SO7 } & 0.91 & 0.13 & 11.16 & 1.04 & 28.82 & 4.45 & 1.57 & 28.33 & 0.28 & 1.98 & 13.9 & 2.11 & 3.29 \\
\hline & \pm & \pm & \pm & \pm & \pm & \pm & \pm & \pm & \pm & \pm & \pm & \pm & \pm \\
\hline & 0.29 & 0.02 & 0.45 & 0.11 & 0.58 & 0.59 & 0.15 & 0.51 & 0.13 & 0.16 & 0.31 & 0.64 & 0.1 \\
\hline \multirow{3}{*}{ SO11 } & 0.61 & 0.1 & 11.9 & 0.99 & 29.39 & 4.48 & 1.32 & 28.85 & 0.25 & 2.03 & 14.92 & 0.74 & 3.44 \\
\hline & \pm & \pm & \pm & \pm & \pm & \pm & \pm & \pm & \pm & \pm & \pm & \pm & \pm \\
\hline & 0.15 & 0.01 & 0.32 & 0.11 & 0.92 & 0.68 & 0.29 & 0.94 & 0.11 & 0.14 & 0.6 & 0.86 & 0.11 \\
\hline \multirow{3}{*}{$\begin{array}{c}\text { SO15 } \\
\text { Rim }\end{array}$} & 0.22 & 0.06 & 12.34 & 0.65 & 29.33 & 3.05 & 0.51 & 32.19 & 0.15 & 1.62 & 16.55 & & 3.65 \\
\hline & \pm & \pm & \pm & \pm & \pm & \pm & \pm & \pm & \pm & \pm & \pm & 0 & \pm \\
\hline & 0.07 & 0.01 & 0.34 & 0.49 & 0.49 & 0.39 & 0.08 & 0.37 & 0.17 & 0.12 & 0.52 & 0 & 0.09 \\
\hline \multirow{3}{*}{$\begin{array}{c}\text { SO15 } \\
\text { Core }\end{array}$} & 0.44 & 0.09 & 12.44 & 0.81 & 29.1 & 4.39 & 0.76 & 30.78 & 0.32 & 1.93 & 15.86 & & 3.57 \\
\hline & \pm & \pm & \pm & \pm & \pm & \pm & \pm & \pm & \pm & \pm & \pm & & \pm \\
\hline & 0.3 & 0.02 & 0.23 & 0.14 & 0.48 & 0.44 & 0.14 & 0.59 & 0.15 & 0.15 & 0.32 & 0 & 0.08 \\
\hline \multirow{3}{*}{ SO17 } & 0.95 & 0.15 & 10.98 & 1.35 & 28.04 & 5.67 & 1.55 & 27.26 & 1.11 & 1.88 & 13.36 & 2.56 & 3.23 \\
\hline & \pm & \pm & \pm & \pm & \pm & \pm & \pm & \pm & \pm & \pm & \pm & \pm & \pm \\
\hline & 0.13 & 0.03 & 0.55 & 0.24 & 1.03 & 1.72 & 0.13 & 0.74 & 2.79 & 0.17 & 0.39 & 0.28 & 0.13 \\
\hline
\end{tabular}

Table 2 
Table 3 SIMS U-Pb zircon data

Radiogenic isotopic ratios

Age (Ma)

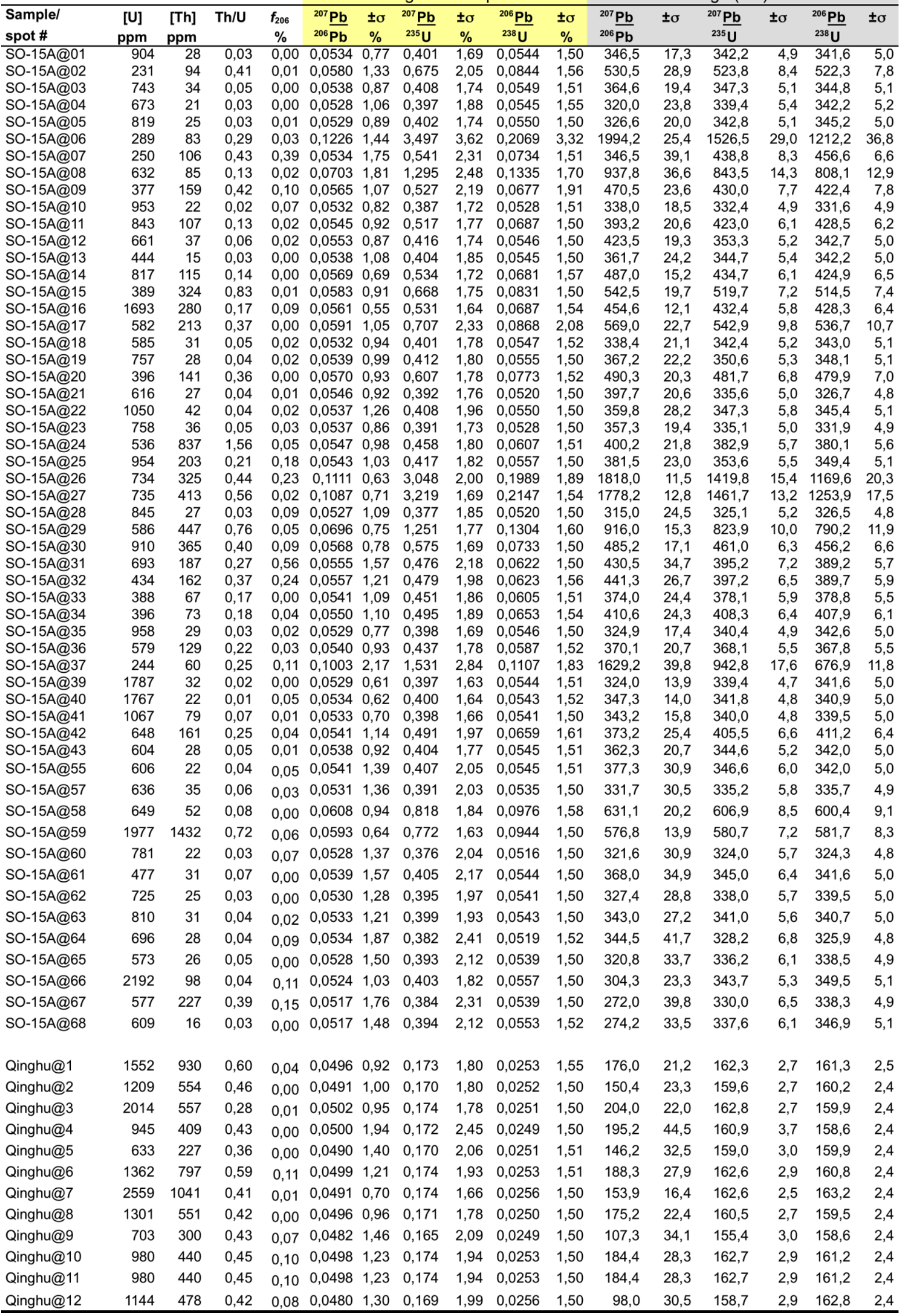

